\title{
A Study of the Genetic Relation between Mawayana and Wapishana (Arawakan Family)
}

Sérgio Meira

Universidade Federal de Roraima (UFRR)

Abstract. This paper presents a first approach at the genetic relation between two Arawakan languages, Mawayana and Wapishana, which have been claimed to form a subgroup in all recent classifications of the family. On the basis of 149 proposed cognate sets, based on data from the available literature and field research on both languages, correspondences are set up and reconstructed proto-phonemes are proposed for the proto-language of what is here called the Pidjanan sub-branch of the Negro-Roraima branch of Arawakan. In conclusion, a description of the historical phonology and of selected aspects of the historical morphology of these languages is offered.

Keywords: Mawayana; Wapishana; Arawakan Languages; Historical Linguistics.

\section{Introduction}

The Arawakan language family is one of the largest linguistic groupings in the American continent, with over 50 languages distributed from Central America (Garifuna) to the Brazil-Paraguay border (Terena) and maybe Argentina (Chané), and from Eastern Peru (Campan languages) to the Xingu river in Central Brazil (Wauja-Mehinaku, Yawalapiti), and to the Brazil-French Guiana border (Palikur). Most Arawakan languages are severely endangered: the vast majority of their over 500,000 speakers belong to one single language, Guajiro (Wayuu), spoken in the peninsula of La Guajiria, shared between Colombia and Venezuela.

Figure 1: Geographic Location of Pidjanan Languages within the Arawakan Family (in blue)

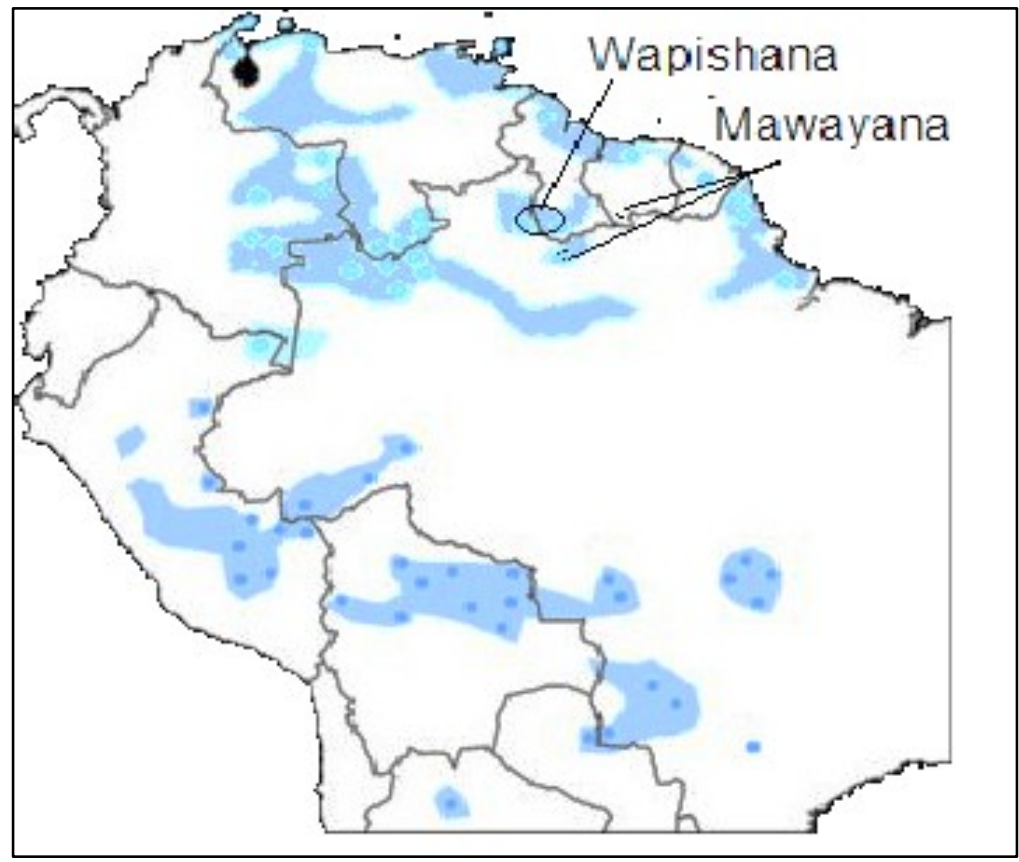

Within Arawakan, two languages are placed together in the most recent classifications, forming (together with other presumably extinct languages) a small sub-branch: Mawayana (aka. 
Mapidian, Maopidian, still spoken by a dozen older people living in Waiwai and Tiriyó villages in Brazil and Surinam) and Wapishana (spoken by over 6,000 people on both sides of the Guyana-Brazil border), as is shown in Fig. 1. Carlin (2006, p. 314) has also briefly noted the close relation between Mawayana and Wapishana.

This article elaborates on Ramírez's work (2001, p. 524-531), the first comparison of these languages) and proposes the term Pidjanan (from Wapishana pidan 'people', found both in 'Wapishana' and in 'Mao-pidian') for the sub-branch that includes them, and probably also Atorad/Atorai. Sec. 2 offers a description of the available data. Sec. 3 shows a short segmental phonology of Pidjanan languages (IPA symbols are used in all examples). Sec. 4 discusses a 100-word Swadesh list that shows the degree of closeness within Pidjanan. Sec. 5 presents the correspondences found in the available data and the reconstructed proto-segments for each of them. Sec. 6 has a sketch of Pidjanan historical phonology and basic morphology. The final Appendix contains a list of all 149 cognate sets found in the available data.

Table 1: The positions of Wapishana and Mawayana in the most recent Arawakan classifications

\begin{tabular}{|c|c|c|c|}
\hline KAUFMAN (1998) & AIKHENVALD (1999) & RAMÍR & RIBEIRO (2011) \\
\hline $\begin{array}{l}\text { - Northern Maipurean } \\
\text { - Upper Amazon } \\
\text { - Maritime branch } \\
\text { - Aruán } \\
\text { - Wapishana, Atorada, } \\
\text { Mapidian } \\
\text { - Ta-Maipurean } \\
\text { - Palikur, Marawán } \\
\text { - Southern Maipurean } \\
\text { - Western branch } \\
\text { - Central branch } \\
\text { - } \text { Southern outlier branch } \\
\text { - Terena } \\
\text { - Moxos group } \\
\text { - Piro group } \\
\text { - Campa branch }\end{array}$ & $\begin{array}{l}\text { - North Arawak } \\
\text { - North Amazonian } \\
\text { - Rio Branco } \\
\text { - Wapishana } \\
\text { - Marvayana } \\
\text { - Caribbean } \\
\text { - Salikur } \\
\text { - South and South-Western } \\
\text { - South Arawak } \\
\text { - South-Western Arawak } \\
\text { - Pareci-Xingu } \\
\text { - Campa } \\
\text { - Amuesha } \\
\text { - Chamicuro }\end{array}$ & 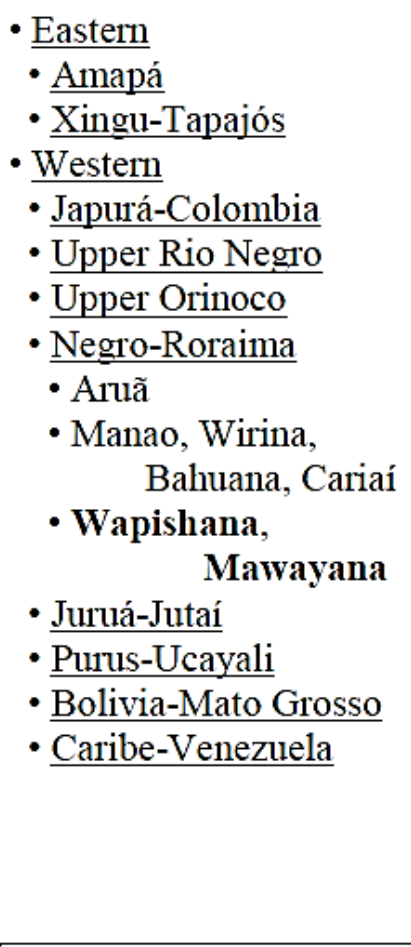 & 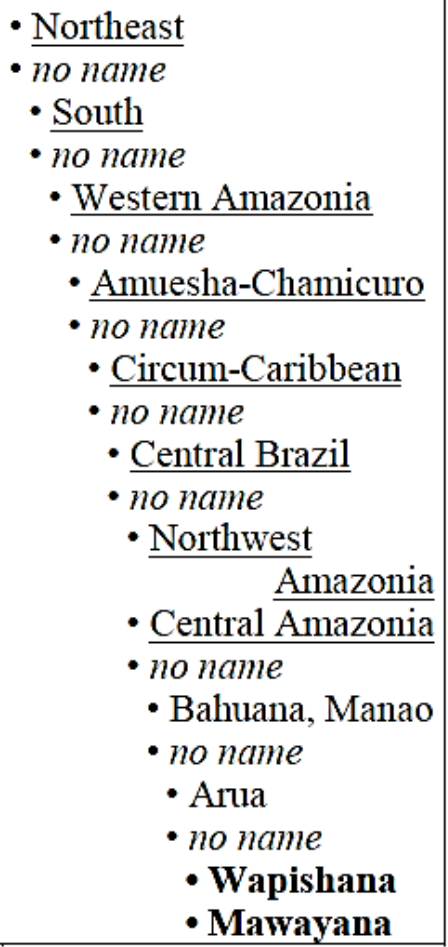 \\
\hline
\end{tabular}

\section{The Data}

For this study, the following sources of data were considered (note that the author's field data were given precedence: other sources were used to complement gaps or to confirm translations, but in general whenever a form was available in the author's data it was chosen for comparison, the assumption being that the other sources were more likely to contain errors): 
For Wapishana:

- The author's field data on Wapishana (a list with a little over 500 lexical items, plus about 200 elicited sentences and two short texts), mostly obtained during the 2010 InField summer school workshops in Eugene, Oregon, from June 21 to July 30, with the help of a native speaker of Wapishana, Mr. Adrian Gomes, and three students: Ana Paula Barros Brandão (UT-Austin), Jessie Erikson, and lan Lunger (UO-Eugene). More data were obtained by the author during two field visits to the village of Marurunau in Guyana, mostly with Mr. Gomes but also with other local people, in the context of collecting data on the Taruma language (new Wapishana lexical items or sentences were obtained as translations for Taruma lexical items).

- Two published dictionaries of Wapishana: WLP 2000, with about 1,400 entries, and Silva, Silva \& Oliveira (2013), with about 1,100 entries.

- Melville, Tracy \& Williams (2007): the IDS (Intercontinental Dictionary Series) list of 1,150 Wapishana entries submitted by C. Melville, F. V. Tracy, and O. Williams, available online at: http://ids.clld.org/contributions/266. Downloaded on Oct. 30, 2007.

- Santos (2006), a grammatical description of Wapishana with a 350-item word list;

- Occasionally, other works on Wapishana grammar (TRACY, 1972; 1974) were used, as well as local publications of texts and literacy materials, of which the most important is WLP 2001. Occasional use was also made of a New Testament translation (SB 2012).

For Mawayana:

- The author's field data, ca. 600 words, 100 sentences and one short text, collected from a native speaker (Tenetene, a 60+-year-old female) in a field trip with Dr. Spike Gildea in 1997, to the Waiwai village of Mapuera, in the Nhamundá-Mapuera Indigenous Area in the State of Pará, in Brazil.

- Howard 1985-1986, a questionnaire (the National Museum Questionnaire, developed by the Federal University of Rio de Janeiro) with about 400 lexical items mostly in phrases and sentences, collected by Catherine Howard in 1985-1986 with a 65-year-old female speaker (Čoowi) from the village of Kaxmi, at the Rio Novo, in the State of Roraima, in Brazil.

- Carlin (no date), a short Mawayana text with Tiriyó, English, and Dutch counterparts, glossed and analyzed by the author; occasionally, also Carlin 2006 (sentence examples in a paper on grammatical borrowings from Cariban into Mawayana).

\section{Transcription and Segmental Phonology}

The transcription of language examples and lexical items in this article uses the IPA only; any material from sources having a different writing system are retranscribed with IPA symbols (note the use of dots to mark syllable boundaries). Table 2, a summary of Pidjanan segmental phonology, shows all the necessary IPA symbols. 
Table 2: A summary of the segmental phonology of Pidjanan languages

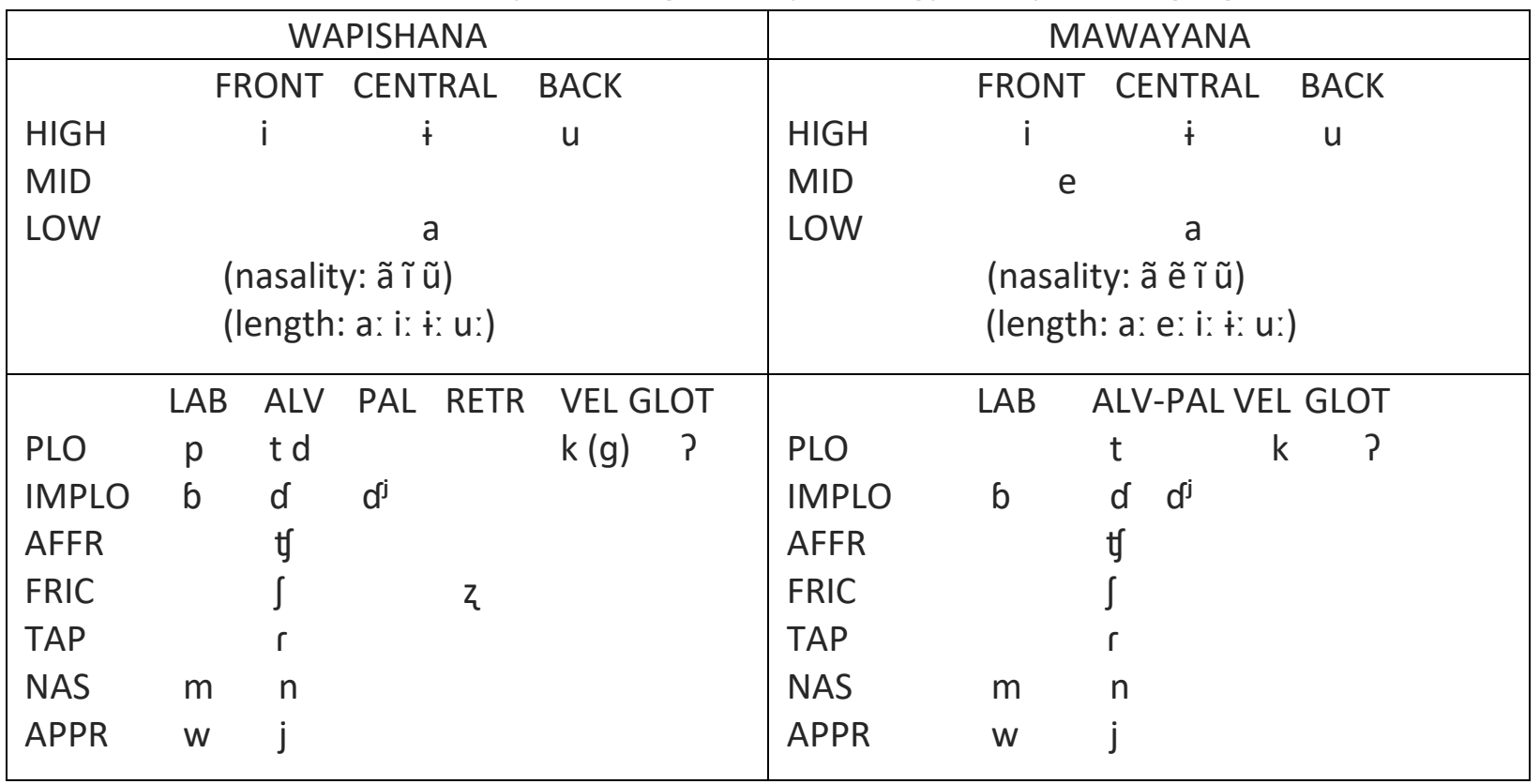

Both Pidjanan languages have phonemic voiced implosives $\left(/ b /, / d /, / d^{j} /\right)$. All implosives sound preglottalized $\left(\left[{ }^{\mathrm{b}} \mathrm{b}\right],\left[{ }^{2} \mathrm{~d}\right],\left[{ }^{2} \mathrm{~d}^{\mathrm{j}}\right]\right)$; sometimes plosive realizations occur $\left(\left[{ }^{\prime} b\right],\left[{ }^{2} d\right],\left[{ }^{2} d^{j}\right]\right.$ or even nonglottalized [b], [d], [dj]). Wapishana has also a normal plosive /d/, much rarer than /d/ but still clearly distinctive (cf. the minimal pair /paradan/ 'to cut underbrush' vs. /paradan/ 'to speak', and analogous pairs like /pidapi/ 'your house' vs. /pidarit/ 'your father'). Another interesting feature of Wapishana is the retroflex fricative $/ z /$, often realized with a simultaneous rhotic feature ([ $\left.[z],\left[z^{t}\right]\right)$.

The vowel system, on the other hand, is richer in Mawayana than in Wapishana: the latter has only 4 vowels $(/ \mathrm{a} /, / \mathrm{i} /, / \mathrm{u} /, / \mathrm{i} /)$, while the former has, in addition, the mid vowel /e/. In both languages, $/ \mathfrak{i} /$ varies from $[\mathfrak{i}]$ to $[\mathrm{m}]$ and $/ \mathrm{u} /$ from $[u]$ to [o] in certain positions; in addition, Wapishana /a/ is raised, often all the way to $[\varepsilon]$, when the preceding syllable ends in a palatal (/i/ or $/ \mathrm{j} /)$ that also affects the intervening consonant: /kaiman/ 'good' $=[$ kaiman $] \sim[$ kaimªn $] \sim[$ kaim(j)æn $] \sim[$ kajm(j)en], /ipaj/ 'all' $=\left[\mathrm{ip}^{\mathrm{j}} \mathrm{aj}\right] \sim\left[\mathrm{ip} \mathrm{p}^{\varepsilon} \mathrm{aj}\right] \sim\left[\mathrm{ip}\left({ }^{\mathrm{j}}\right) æ \mathrm{j}\right] \sim\left[\mathrm{ip}\left({ }^{\mathrm{j}}\right) \varepsilon j\right]$. Both languages have nasal vowels, though these are rather rare, especially in Wapishana, where most nasal vowel tokens are either the first-person singular prefix /ũ-/ 'I', 'my' or the third-person plural prefix /î-/ 'they', 'their'. In Mawayana, nasal vowels tend to spread through glides, nasalizing the next vowel: /kẽje/ 'arrow' = ['kẽ̃ẽ] ['kẽnẽ]; /tõwa/ 'sleep' = [tõwã] [tõw̃̃̃]. Wapishana has distinctive long vowels. Mawayana appears to have some as well, but most cases of phonetic long vowels are the result of stress (e.g., /jimada/ 'jaguar' = [ji.'ma:.da]).

Both Wapishana and Mawayana have intensity stress, placed on the penultimate mora of a phonological word (i.e., if the final syllable is $\mathrm{CV}$, then the penultimate syllable is stressed; if the final syllable is CVC or CVV, the final syllable is stressed; cf. Wapishana /pitikapa/ 'look!' [, pitt'kapa] and

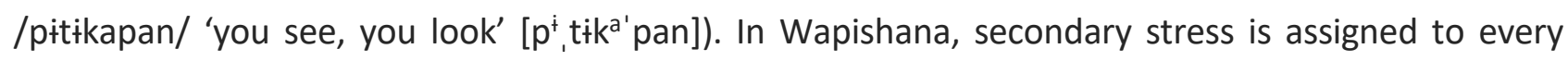
second syllable, counting backwards from the syllable with primary stress, as the 'look' examples show. Unstressed vowels in CV syllables often become voiceless and can almost completely disappear, especially after nasals or fricatives (/kiba/ 'stone' = ['ki.ba] $\sim$ ['ki.ba] ] ['kib]; /zina/ 'woman' = ['zit.n ${ }^{\text {a] }}$

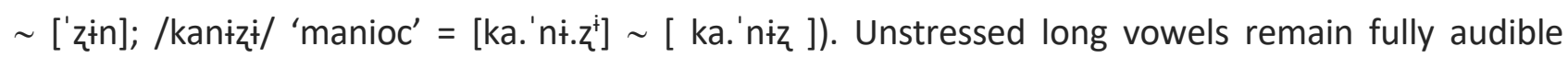




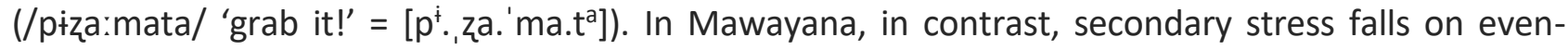
numbered CV syllables from the beginning to the end of the word (/wa-katuku-st/ [wa., ka:.tu.' ku:.si] 'our club, stick'); non-CV syllables are always stressed (/awjada/ ['aw.ja.da] 'toucan sp.'). Unlike Wapishana, Mawayana stress is thus sensitive to prefixes, not suffixes (e.g., /kanawa/ [ka.'na:.wa] 'canoe', /wa-kanawa/ [wa.'ka:.na.wa] 'our canoe'). Stressed vowels are usually lengthened; unstressed vowels, though unlengthened, do not reduce or disappear, unlike Wapishana unstressed vowels. The same pattern is attested in Cariban languages, including neighboring Waiwai.

As the previous paragraph has already shown, the attested syllable types in both languages are CV, CVV (VV being either a long vowel or two different vowels, always stressed on the first vowel: /ai/ = ['ai] = [aj], not [a'i]) or CVN, where $\mathrm{N}$ is a nasal coda consonant. In Wapishana, there are distributional restrictions: $/ \mathrm{w} /$ cannot precede $/ \mathrm{u} /$, and the palatal consonants $/ \mathrm{j} /, / \mathrm{d}^{\mathrm{j}} /, / \mathrm{n} /$ cannot be followed by /i/ (also, /n/ only precedes / $\mathrm{i} /$ ). In Mawayana, the nasals $/ \mathrm{n} /$ and $/ \mathrm{m} / \mathrm{can}$ also occur as the syllabic nucleus word-initially, followed by homorganic consonants: /n.taru/ 'my mother', /n.ruba/ 'my foot', /n.ni/ louse', /m. buka/ 'to me'. Almost all cases, with only a handful of exceptions like 'louse', are instances of use of the first-person prefix $/ \mathrm{n}-/$.

\section{Swadesh List and Shared Cognates}

As an initial assessment of the degree of similarity and relatedness between Pidjanan languages, we consider the 100-word Swadesh list below (the version published in Swadesh 1971, p. 283).

In this list, cognate words are marked in bold, while non-cognate words are in normal type. Partially cognate words (i.e., words which contain non-cognate elements, as in, e.g., Portuguese nós 'we' and Spanish nosotros 'we', where the otros part is not cognate) are counted as fully cognate words, even though only their cognate part is written in bold. Notice that both languages are also (as is frequent in the Arawakan family) morphologically complex, which leads to many example words containing affixes. These are segmented out with hyphens and left in normal type.

Table 3: 100 -word Swadesh list for Pidjanan languages. $44 \%$ of the words are cognates.

\begin{tabular}{|c|c|c|c|c|c|c|}
\hline ITEM & MAWAYANA & WAPISHANA & & ITEM & MAWAYANA & WAPISHANA \\
\hline I & nnu & ũgarit & 51. & BREAST & ri:-di & $\dot{i}-d i n \dot{t}$ \\
\hline YOU (SG.) & $\mathbf{i}$ & pigarł & 52. & HEART & ri:?-ĩkĩjã & i-nikini: \\
\hline WE (INCL.) & we?awinu & wainau & 53. & LIVER & $r \dot{t}-\int u b a$ & i-kiba: \\
\hline THIS & ti?a & wirit?i & 54. & DRINK & kura-si & i-tiza-n \\
\hline THAT & aru & wirit?i & 55. & EAT & r-ĩka & $\dot{t}-n \dot{i} k a-n$ \\
\hline WHO & ka & kanum & 56. & BITE & awtfa-si & $\dot{t}$-aruta-n \\
\hline WHAT & ka & kanum & 57. & SEE & ri-tfika-st & t-tika-pa-n \\
\hline NOT & tika, ma-si & auna: & 58. & HEAR & 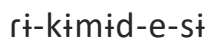 & $\dot{+}$-abata-n \\
\hline ALL & meke-nu & ipai & 59. & KNOW & rit-rud-e-sit & i-aitapa-n \\
\hline MANY & rea-nu & iriba-?u & 60. & SLEEP & a-tũwa & $\dot{t}-d a$ Pawi-n \\
\hline ONE & abõ(i)ja & baida?apa & 61. & DIE & mawda & $\dot{t}$-mau-ka-n \\
\hline TWO & adaka & $\mathrm{d}^{\mathrm{j} a} \mathrm{pittam}$ & 62. & KILL & ru-kuda & $\dot{t}$-zuwia-n \\
\hline BIG & tawre-re & trdarti-?u & 63. & SWIM & tokwa-si & $\dot{t}-n \dot{t o t a}-n$ \\
\hline LONG & ki?u-re & zapabapł & 64. & FLY & mar-e-sit & $\dot{i}-z \dot{t}+\dot{t} t a-n$ \\
\hline SMALL & fidjidja-re & sodi & 65. & WALK & ru-suka & i-tfipika-n \\
\hline WOMAN & rinaru & zina & 66. & COME & jad-e & i-wa?ati-n \\
\hline MAN & asina & daunajura & 67. & LIE & tukud-e-si & $\dot{t}$-waJatina-n \\
\hline PERSON & $d^{j} e$ & pidan & 68. & SIT & itad-e-sł & ¡-sakanata-n \\
\hline
\end{tabular}




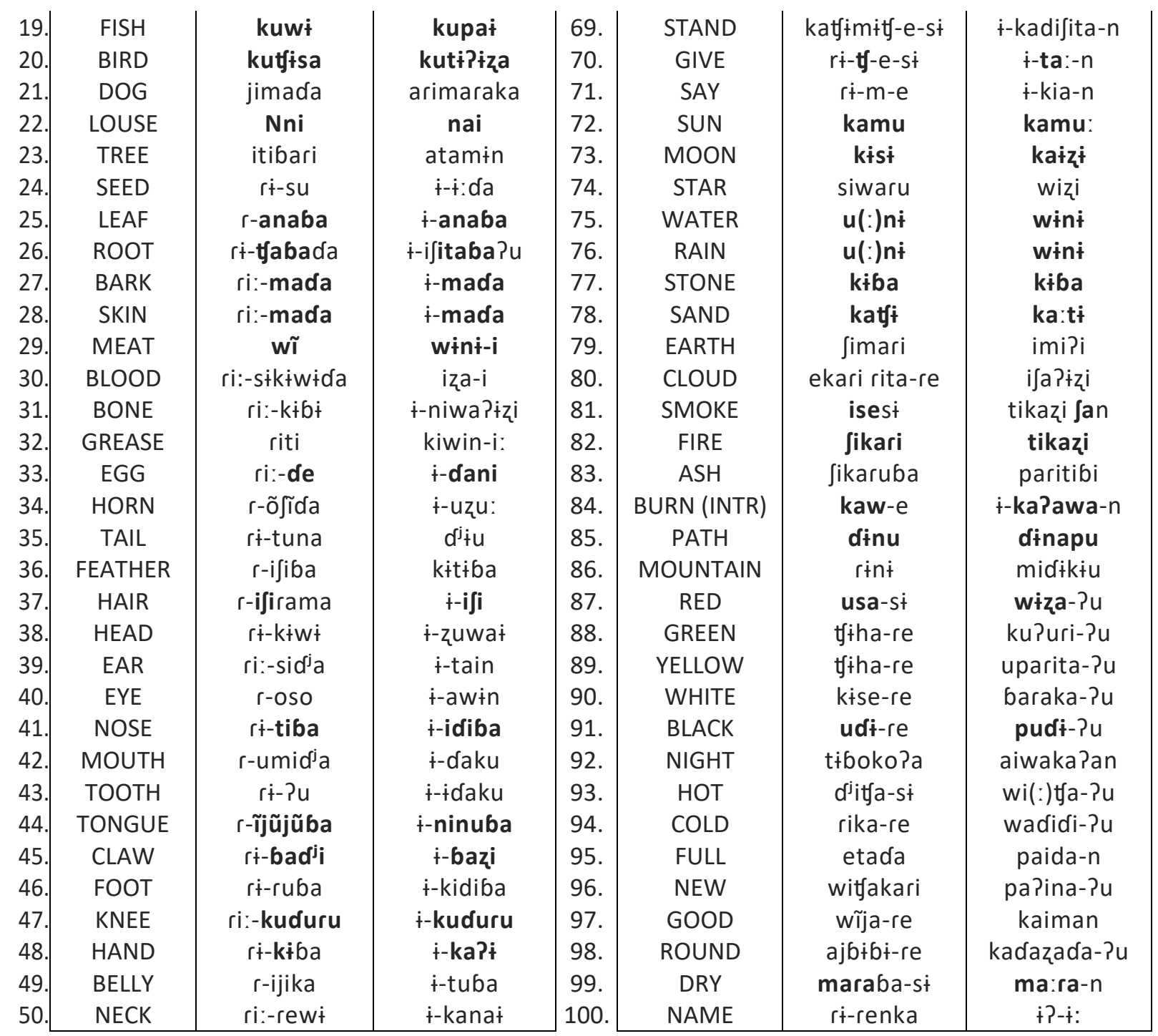

The percentage of fully or partially cognate terms (the cognate parts are in bold) is 44/100 or $44 \%$. If duplicates ( 6 and 7, 27 and 28,75 and 76) are counted as only one instead of two, the result is $41 / 97$ or $42,3 \%$. This is a rather low result for languages considered to be closely related in all classifications (see Table 1 above). The neighboring Cariban languages (Makushi, Taurepang, Ingariko) average 70-75\%; even if one includes less closely related languages to the southeast of the Rio Branco (Waiwai, Hixkaryana), shared cognacy still remains at $50 \%$ or more. This suggests that, in this area (from the upper Rio Branco in Brazil eastwards into the Rupununi area in Region 9 in Guyana), Arawakan groups have lived for a significant longer period of time than Cariban groups, thus agreeing with current theories on the Arawakan and Cariban expansions.

\section{Correspondences and Proto-Segments}

In this section, we discuss the vowel (Sec. 5.1) and consonant (Sec. 5.2) correspondes found in the data listed in the Appendix ${ }^{1}$.

\footnotetext{
${ }^{1}$ Note that recurring elements ( $\mathrm{ba}, \mathrm{da}, \mathrm{ka}$, pa, etc., probably old derivational affixes), often found in one cognate but not in the other, will be ignored. Only when the same element is present in both cognates will it be reconstructed.
} 


\subsection{Vowel correspondences.}

In this section, we examine all Pidjanan correspondences involving vowels.

\subsubsection{Main Vowel Correspondences.}

Table 4 summarizes the main correspondences involving vowels, listing examples for each correspondence (an ellipsis (...) at the end of the list of examples means that there are more examples of that correspondence in the data in the Appendix; if there is no ellipsis at the end, the list is complete). A possible reconstruction for each correspondence, marked with a preceding asterisk $(*)$, is given in the first column (PP $=$ Proto-Pidjanan). Subscript numbers $\left({ }^{*} \mathrm{v}_{1},{ }^{*} \mathrm{v}_{2},{ }^{*} \mathrm{v}_{3}\right.$, etc.) identify different correspondences potentially reconstructible as the same proto-segment $\left({ }^{*} \mathrm{v}\right)$. The reconstruction is discussed in the paragraphs following each table.

Table 4: Correspondences involving vowels in Pidjanan languages.

\begin{tabular}{|c|c|c|l|}
\hline PP & MAWAYANA & WAPISHANA & EXAMPLES \\
\hline${ }^{*} \mathrm{a}_{1}$ & $\mathrm{a}$ & $\mathrm{a}$ & AÇAÍ, ACOUCHY, BAT, CAPYBARA, CORN, FRUIT, MOTHER... \\
${ }^{*} \mathrm{u}_{1}$ & $\mathrm{u}$ & $\mathrm{u}$ & AÇAÍ, ACOUCHY, CAPYBARA, FISH, TIMBÓ LIANA, TAPIR... \\
${ }^{*} \mathrm{i}_{1}$ & $\dot{\mathrm{f}}$ & $\dot{\mathrm{t}}$ & BURITI PALM, BRAZIL NUT, FISH, PET, SALT, WIND, WOMAN... \\
${ }^{*} \mathrm{i}_{1}$ & $\mathrm{i}$ & $\mathrm{i}$ & ACOUCHY, CURASSOW, FAN, FIRE, FROM, INGÁ, PAYMENT,... \\
${ }^{*} \mathrm{e}_{1}$ & $\mathrm{e}$ & $\mathrm{i}$ & ARMPIT, CHILD, KNIFE, PARTNER, THIN, TOUCAN SP. \\
${ }^{*} \mathrm{e}_{2}$ & $\mathrm{e}$ & $\mathrm{a}$ & CHILD, CHILD/EGG, FISH SP 1, PERSON, SMOKE. \\
${ }^{*} \mathrm{o}_{1}$ & $\mathrm{o}$ & $\mathrm{a}$ & CICADA, LEFT-HAND. \\
${ }^{*} \mathrm{o}_{2}$ & $\mathrm{o}$ & $\mathrm{u}$ & MONKEY SP 3. \\
\hline
\end{tabular}

From these correspondences, the four vowels $*_{a}, *_{i}, *^{u}$, and $*_{i}$ can be easily reconstructed: they all have numerous examples ( ${ }^{*} a_{1}$ occurs in over $63 \%$ of all cognate sets, ${ }^{*} u_{1}$ in $35 \%,{ }^{*} \dot{i}_{1}$ in $26 \%$, and $* i_{1}$ in $24 \%$ ) and are found in all environments.

The two other possible vowels, a front mid *e and a back mid ${ }^{*}$ o, are less clear. The plausible candidate correspondences, ${ }^{*} \mathrm{e}_{1},{ }^{*} \mathrm{e}_{2}$ and ${ }^{*} \mathrm{o}_{1}$, have better explanations: ${ }^{*} \mathrm{e}_{1}$ has only six examples, all involving Wapishana a and i, either in the same syllable (CHILD: M kurenu, W kuraidauna:) or in adjacent syllables (ARMPIT: M ke:su, W kifapu, PARTNER: M me:rawa, W minai-da?i, THIN: M metada, W mida-Pi), as does * $e_{2}$ (CHILD/EGG: $M$ de, W dani, FISH SP. 1: M ri:tje, W zii:ta-ba, PERSON: M dje(:), W pidan, SMOKE: M ise-si, W ifa-n). Those examples are better reconstructed as cases of *a and $*_{\mathrm{i}}$, with these vowels either merging ( ${ }^{*}$ ai $>\mathrm{e}$ is a common change cross-linguistically) or raising to e (ato-e or i-to-e raising; notice that a preceding $\mathrm{i}$, as was pointed out in Sec. 3, is the environment in which Wapishana a raises to $æ \sim$ e) in Mawayana. The only difficult example is * $e_{1}$ TOUCAN SP. (M takwe, $\mathrm{W}$ tJa:kui), in which the same i and a environment is still present, but the intervening ku / kw suggests a more complex story (maybe originally more than one syllable, e.g., $\left.{ }^{*} k u-w e\right)$. There is thus very little basis for reconstructing PP * $e$. Further instances of $*^{*} a$ and $*_{i}$ are reconstructed instead.

Finally, ${ }^{*} \mathrm{O}_{1}$ and ${ }^{*} \mathrm{O}_{2}$ are even less clear. Two out of three examples, CICADA (M womu, W wamu) and MONKEY SP. 3 ( $\mathrm{M}$ ot $f \mathrm{i}, \mathrm{W}$ puwati), have adjacent $\mathrm{w}$ 's that suggest assimilation: PP ${ }^{*}$ wamu $>$ M womu, * puwat $>$ * puwoti $>$ * puot $>$ * poti $>$ *ot $>$ otf (for Mawayana $p$-loss and *t $>$ $t$, see Sec. 5.2.1, 5.2.2). Only ${ }^{*} \mathrm{o}_{3}$ LEFT-HAND (M asuba-, $W$ afaba-) remains. Even if one suspects 
that the labial $b$ may have influenced the preceding $a$, it would still be an idiosyncratic change. Note also that Mawayana o is quite rare and apparently non-phonemic (no minimal pairs for $o$ and $u$ have been found). It is currently analyzed as an allophone of $/ \mathrm{u} /$, so that ot $f \dot{i}$ and womu are /ut $\mathrm{f} /$ and /wumu/. Therefore, ${ }^{*} \mathrm{o}_{1}$ is reconstructed as $*$ a and ${ }^{*} \mathrm{o}_{2}$ as $* \mathrm{u}^{2}$

\subsubsection{Correspondences Involving Vowel Loss.}

Table 5 lists vowel correspondences in which one of the two Pidjanan languages lacks a reflex.

Table 5: Correspondences involving vowels and zeros in Pidjanan languages.

\begin{tabular}{|c|c|c|c|}
\hline $\mathrm{PP}$ & MAWAYANA & WAPISHANA & EXAMPLES \\
\hline$* a_{2}$ & $\varnothing$ & a & ARMPIT, BIRD SP. 1, BLOW, BRAZIL NUT, COMB, FISH, PATH... \\
\hline$*^{*} a_{3}$ & a & $\varnothing$ & BAT, BUTTERFLY, CAJÁ, COCKROACH, HEART, IGUANA... \\
\hline$* i_{2}$ & $\varnothing$ & $\mathrm{i}$ & NOSE, PAYMENT, PERSON. \\
\hline$*_{i_{3}}$ & $\mathrm{i}$ & $\varnothing$ & INTESTINES, SEAT, SMOKE. \\
\hline${ }^{*} \mathrm{u}_{2}$ & $\varnothing$ & u & COATI, HIT, MONKEY SP. 3, TAPIR. \\
\hline${ }^{*} u_{3}$ & u & $\varnothing$ & VULTURE. \\
\hline$*_{\dot{t}_{2}}$ & $\varnothing$ & $\grave{t}$ & BREAST, MANIOC, MEAT FOOD, SONG, TORTOISE, WATER... \\
\hline$*_{\dot{t}_{3}}$ & $\dot{t}$ & $\varnothing$ & FLOWER, MEDICINE, SHAMAN. \\
\hline
\end{tabular}

For $* a_{2}, * i_{2}, * u_{2}$, and $* \dot{i}_{2}$, most of the cases result from one change, here called Mawayana diphthong reduction. These are cognate sets in which a Wapishana diphthong (or VPV or VpV sequence, as in 1h-i; see Sec. 5.2.1, 5.2.6 on *p- and *?-loss) corresponds to a Mawayana simple vowel, the same as the last vowel of the Wapishana diphthong ( $1 \mathrm{a}-\mathrm{c}, \mathrm{f}-\mathrm{g}$ ) except for $* \mathrm{e}_{2}$ cases, in which $\mathrm{M}$ e corresponds to $\mathrm{W}$ ai (1d; note $1 \mathrm{e}$ is irregular, probably because it is a monosyllable). ${ }^{3}$ In these cases, $*$ ai is reconstructed. Elsewhere, ${ }^{*} a_{2}, *^{*}{ }_{2},{ }^{*} u_{2}$, and $*^{*} \dot{i}_{2}$ are reconstructed as $* a, *_{i}, *^{*}$, and $*_{\dot{t}}$, respectively.

(1) Examples of Mawayana diphthong reduction.
a. BRAZIL NUT: *minał > $\mathrm{M}$ mini, $\mathrm{W}$ minał
b. BIRD SP. 1: *anarau $>M$ anaru, $W$ anarau
c. COATI: *kuad $\dot{j}>\mathrm{M}$ kadi, W kuatfi
d. SEAT: *(i)tabai $>M$ isabe, $W$ tabai ${ }^{4}$
e. LOUSE: *nnai >M nni, W nai
f. TAPIR: *kudui > M kudi, W kudui
g. SONG: *kinii > M kini, W kinii
h. PAMYMENT: * winipa $>M$ wina, $W$ winipa
i. HIT: *ruPita- > M rita-, W zu?ita-

$\left({ }^{*}\right.$ winipa $>*$ winia $>M$ wina $)$
$\left({ }^{\text {ruPita }}>*^{*}\right.$ ruita $>M$ rita $)$

${ }^{2}$ Note, however, that not all cases of PP *a and *i in adjacent syllables resulted in M e (e.g., FIRE: M Jikari, W tikazi,
CLAW/NAIL: M badji, W bazi, NOSE: M tiba, W idiba, BRAZIL NUT: M mini, W minai), nor do all cases of PP *wa turn into
M wo (e.g., AÇAí: M wabu, W wabu). The intervening consonant seems to be a factor, but the exact rule remains unclear.
${ }^{3}$ In the nearest related language, Bahuana, similar cases of diphthong reduction occur optionally: mainda 'not', jai
'interrogative' become respectively minda, ji in fast speech (RAMíREZ, 1992, p.28). In Mawayana, the same type of
reduction has seemingly progressed to the point in which only the shorter form remains.
${ }^{4}$ Interestingly, Mawayana diphthong reduction has led to possessive alternations such as isabe 'seat (non-possessed)',
kini 'song (non-possessed)' vs. isaba 'seat (possessed)', kinit 'song (possessed)' in, e.g., wa-kini 'our song', wa-isaba 'our
seat', with the 1pl prefix wa-. The corresponding Wapishana cognates involve the suffix -i, which marks non-possessed
forms: kini-i 'song-NON.POSSESSED', taba-i 'seat-NON.POSSESSED' vs. wa-kini 'our song', wa-taba 'our seat'. This
supports the reconstruction of a PP suffix *-i, marking the non-possessed form of usually possessed nouns. 
Some of the $*_{\dot{t}_{2}}$ cases listed below can be explained by reconstructing, based on the Wapishana cognate, PP * wit, and by positing a (word-initial) assimilatory change * $w \dot{+}>M$ u(:).

(2) Examples of PP *wi $>M u$.

a. WATER: *wini $>M$ u(:)ni, $\mathrm{W}$ winit

b. RED: *wira- > M usa-si, W wiz̨a-Pu

c. TORTOISE: * wirV > M u:rit, W wira-da

Some cases of apparent Wapishana word-final vowel loss $\left(*_{a_{3}}, *_{i_{3}}, *_{u_{3}}, \dot{i}_{3}\right)$ are probably spurious: as mentioned in Sec. 3, unstressed (among which word-final) vowels in Wapishana tend to reduce and even disappear, but are still reconverable when certain elements (e.g., the relativizing clitic $-z$ ) are added. In these cases (3a-f), the Mawayana final vowel is reconstructed (i.e., *a, *i, *u, $*_{\dot{i}}$, respectively). In (3e-g), the disappearing a is not always word-final, but it is still unstressed; it is therefore also reconstructed as *a.

(3) Examples of apparent word-final vowel loss in Wapishana
a. SHAMAN: *marinawi > M marinawi, $W$ marinau
b. VULTURE: *kurumu $>$ M kurumu, W kurim
c. CAJÁ: *ru:ba > M ruba, W zu:p
d. HEART: *nikinija > M îkĩã, W nikini:
e. BUTTERFLY: *tsamatsama > M samasama, W tamtam
f. IGUANA: *suwana > M suwana-da, W suwan
g. DIE: *mawa- > M maw-da, W mawa-ka, mau-ka-n

A few * ${ }_{2}$ cases result from the Mawayana tense-aspect-mood suffix -e replacing stem-final a (4a-d). ${ }^{5}$ This means that these are actually cases of the regular * $a_{1}(a: a)$ correspondence, the lack of an a-final stem variant (used in other tense-aspect-mood forms) being simply a spurious gap in the data. In (4d), note both Wapishana loss of unstressed stem-final a and Mawayana replacement of stem-final a with -e.

(4) Examples of a-loss due to verbal morphology and/or stress placement
a. BLOW: *pu:ta > M utf-e, W pu:ta-
b. BURN: *ka?awa > M kaw-e, W ka?awa-
c. GIVE: *ta: > M tf-e-si, $\mathrm{W}$ ta:-n
d. BATHE: *kawa > M kaw-e, W kau-pa-n

A few irregular cases remain. In FRUIT ( $\mathrm{M}$ ri-ka, W $\dot{\mathrm{i}}-\mathrm{aka}$ ), the lack of an initial a is unexpected. With a-initial stems, the Mawayana third-person marker ri- usually undergoes diphthong reduction (ri-a > ra(:); ara 'talk, language', ra-ara [ra:ra] 'his talk'; anaba 'leaf', r-anaba, ra-anaba [ra:naba] 'its leaf'); with FRUIT, however, this did not happen. It is thus not clear whether the corresponding PP stem had an initial vowel or an initial consonant. A parenthetical vowel is added to the reconstruction $(*(a) k a)$ to signal this uncertainty. Similarly, NOSE (M rit-tiba, W i-idiba) and PERSON (M

\footnotetext{
${ }^{5} \mathrm{~A}$ more interesting hypothesis is that the stem-final vowel a could have been raised to e by a following *i. If the tenseaspect-mood suffix is reconstructed as *-ni (or *-ni, given W cognate -ni 'REALIS') then n-loss without nasalization would lead to stem-final *ai and then $\mathrm{M}$ e (see *e2; see also Sec. 5.2.5 for n-loss, Sec. 6.1 for basic morphology).
} 


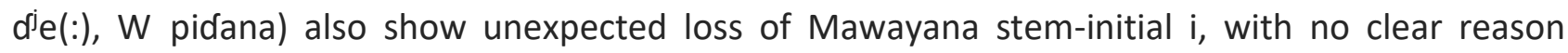
(diphthong reduction would lead to ri(:)-, not ri-), and SEAT (M ri?-isaba, W i-taba) shows a similar loss in Wapishana. For NOSE and SEAT, a parenthetical *(i) is added; for PERSON, given the palatalized $d^{j}$ in Mawayana, $*_{i}$ is reconstructed. For SMOKE (M ise-si, $W$ ifa-n), the initial $i$ is conserved in some of the Wapishana forms (i.e., the loss is not complete) and is thus reconstructed as *i. For a few more cases of loss (PAPAYA, OTHER, etc.), see Sec. 5.2.1, 5.2.6 (*p and *?).

\subsubsection{Idiosyncratic Vowel Correspondences}

The remaining non-identical vowel correspondences, listed in Table 6 below, mostly involve idiosyncratic changes, often more than one per cognate set. In some cases, the words in the set may not even be really cognate. For specific details on changes within each set, see the Appendix.

Table 6: Idiosyncratic vowel correspondences in Pidjanan languages.

\begin{tabular}{|c|c|c|c|}
\hline $\mathrm{PP}$ & MAWAYANA & WAPISHANA & EXAMPLES \\
\hline$* a / u$ & a & $\mathrm{u}$ & ARMADILLO SP., INAJÁ. \\
\hline$* u / a$ & u & a & ARMADILLO SP., OTHER. \\
\hline$* a / \dot{t}$ & a & † & PECCARY SP. 1. \\
\hline$* \grave{i} / a$ & $\dot{q}$ & a & BACABA, TORTOISE, TRUMPETER \\
\hline$* e / \varnothing$ & e & $\varnothing$ & MANIOC PRESS. \\
\hline$*_{\mathrm{i} / \mathrm{a}}$ & $\mathrm{i}$ & a & FAN, TICK. \\
\hline$*_{\mathrm{i} / \mathrm{u}}$ & $\mathrm{i}$ & u & SMALL. \\
\hline$* u / i$ & u & i & MONKEY SP. 1, TICK, WALK. \\
\hline$*_{i} / \mathrm{i}$ & $\mathrm{i}$ & $\Varangle$ & HEART, INAJÁ, SEE, WITH. \\
\hline$*_{i} / \mathrm{i}$ & $i$ & $\mathrm{i}$ & BELT, COATI, TRUMPETER. \\
\hline$*_{\mathrm{i}}^{\mathrm{i}} \mathrm{u}$ & $\dot{i}$ & u & FLOWER, TELL. \\
\hline$* u / \mathfrak{t}$ & $\mathrm{u}$ & $\dot{t}$ & GRANDMOTHER, VULTURE SP. \\
\hline
\end{tabular}

\subsubsection{Correspondences Involving Suprasegments}

Finally, there are correspondences involving suprasegmental features like vowel nasality, vowel length and stress.

Table 7: Correspondences involving suprasegmental features (vowel nasality, vowel length).

\begin{tabular}{|c|c|c|l|}
\hline PP & MAWAYANA & WAPISHANA & \multicolumn{1}{|c|}{ EXAMPLES } \\
\hline$* \tilde{V}_{1}$ & $\tilde{V}$ & $\mathrm{~V}$ & EAT, HEART, HOUSE, MANIOC, MEAT FOOD, ROPE, TONGUE. \\
$* \tilde{V}_{2}$ & $\mathrm{~V}$ & $\tilde{V}$ & I. \\
$* \mathrm{~V}_{1}$ & $\mathrm{~V}:$ & $\mathrm{V}$ & ARMPIT, BIRD SP. 2, MANIOC, PARTNER, PERSON, TORTOISE. \\
$* \mathrm{~V}_{: 2}$ & $\mathrm{~V}$ & $\mathrm{~V}:$ & AS, BANANA, BEADS, BEE/HONEY, BELT, BLOW, CAJÁ, DRY... \\
\hline
\end{tabular}

Vowel nasality is not reconstructible: all examples have nasal vowels corresponding to oral vowels adjacent to $n$, thus suggesting PP ${ }^{*} V n$ or ${ }^{*} n V$ sequences in which the consonant nasalized neighboring vowels and disappeared. ${ }^{6}$ This means that $* \tilde{V}_{1}$ and ${ }^{*} \tilde{V}_{2}$ are actually subsets of ${ }^{*} n_{2} /{ }^{*} n_{4}$ and ${ }^{*} n_{3}$, reconstructed as ${ }^{*} n$ and ${ }^{*}$. For further details, see Sec. 5.2.5 below.

\footnotetext{
${ }^{6}$ Most such cases $\left(* \tilde{V}_{1}\right)$ occurred in Mawayana; only one example $\left(* \tilde{V}_{2}\right)$ shows nasalization in Wapishana (I: M nnu, W ũ-gari). Wapishana has very few nasal vowels: other than the person prefixes ũ- ' 1 sg.' and ĩ- ' 3 pl.', from PP *nu- and (presumably) *ni-, one finds only the reflexive/detransitivizer suffix -ĩ, still in synchronic variation with -in, and borrowings like parãka 'plank, board' (from Eng. plank or Port. prancha 'board'). Wapishana nasalization is thus a rare, irregular phenomenon.
} 
As for vowel length, most of the cases of $V_{i_{1}}$ in Table 7 appear to be the result of compensatory lengthening, in that the corresponding Wapishana cognates have one extra syllable. These are reconstructed with an extra syllable and without length $(5 a-d) .{ }^{7}$ The cases of $V_{i 2}$, on the other hand, show Wapishana longvowels in all kinds of environments in the two last syllables of a word (5e-g). Sometimes the final long syllable alternates with an extra syllable (5g), sometimes it does not (5e-f). In the cases where synchronic alternation is attested, the extra syllable is reconstructed; if not, the long syllable is reconstructed.

(5) Examples of correspondences involving long vowels ${ }^{8}$
a. ARMPIT: *kisapu > M ke:su, W kifapu
b. BIRD SP. 2: *ma(r)ati > M ma:ti, W marati

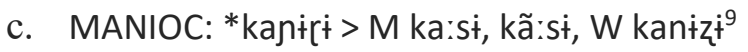
d. TORTOISE: *wirV > M u:rit, W wira-da
e. FLAT AREA: * da:ra $>M$ dara, $W$ da:ra
f. SUN: *kamu: > M kamu, W kamu:
g. KNIFE: *marija > M mare, W mari., i-marija-n

Turning now to stress, as was seen in Sec. 3, the Wapishana and the Mawayana systems differ in directionality: the former counts syllables from the end of the word, while the latter counts syllables from the beginning of the word. Note, however, that the latter corresponds exactly to the rhythmic stress system found in Cariban languages, among which Waiwai and Tiriyó (see Meira, 1998 for a Tiriyó case study). The few remaining Mawayana speakers live currently in Waiwai and Tiriyó villages in Brazil and in Suriname, where all conditions for borrowing are present (see Carlin, 2006 for examples of grammatical loans). Under these circumstances, it seems more likely that Mawayana has simply borrowed from Cariban. The Wapishana system is thus reconstructed to Proto-Pidjanan: counting from the last syllable of a word, secondary stress is assigned to every other CV syllable. Non-CV syllables are always stressed, and syllable counting restarts after them. Primary stress goes to the penultimate mora (i.e., to the final syllable if it is non-CV, or then to the penultimate if the final syllable is $\mathrm{CV}$; in other words, to the first of all secondarily stressed syllables, counting from the end of the word). Mawayana unstressed vowels are never dropped, while Wapishana unstressed vowels often are; it seems better to reconstruct Proto-Pidjanan unstressed vowels as similar to their Mawayana counterparts, i.e., less salient, but not really strongly reduced or lost. Unstressed vowel loss is thus an ongoing Wapishana innovation.

\footnotetext{
${ }^{7}$ Note, however, that not all cases of syllable loss have this effect. For example, the lengthening in PERSON (M d ${ }^{j} e, d^{j} e:$, W pidana) and WATER (M uni, u:ni, W wini) is apparently optional, and is absent in other cases (PAPAYA: M mabaja, W ma?apai; MEAT FOOD: M wĩ, W winiti; RED: M usa-si, W wiza-?u; CHILD/EGG: M de, W dani; cf. PERSON). It is not clear whether this results from incorrect transcriptions in the original sources, or has some diachronic significance (e.g., it might indicate ongoing loss of vowel length in Mawayana). Further research is necessary on this topic.

${ }^{8}$ It is possible that more, maybe all, Pidjanan long vowels ultimately derive from lost syllables: compare, e.g., SUN (5f above) with words from related languages, like Guinau gamúhu, Manao gamuy 'sun' (RAMíREZ, 2001, p. 584), which suggest a pre-Proto-Pidjanan extra syllable at the end.

${ }^{9}$ In this example, Mawayana diphthong reduction would have yielded *kisi or *kĩsí, and a simple block of this change

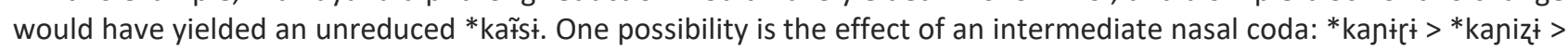
*kan'izi > *kansì > M ka:sì, kã:sł.
} 


\subsection{Consonant correspondences}

In this section, we examine all Pidjanan correspondences involving consonants.

\subsubsection{Correspondences Involving Non-Alveopalatal Stops}

The simplest consonant correspondences in Pidjanan are those involving the voiceless stops $\mathrm{k}$ and $p$, as listed in Table 8 below.

Table 8: Correspondences involving $k$ and $p$ in Pidjanan languages.

\begin{tabular}{|c|c|c|l|}
\hline PP & MAWAYANA & WAPISHANA & EXAMPLES \\
\hline${ }^{*} \mathrm{k}_{1}$ & $\mathrm{k}$ & $\mathrm{k}$ & ANT SP, ARMIT, BATHE, BEADS, BIRD, BIRD SP. 3, BURN... \\
${ }^{*} \mathrm{k}_{2}$ & $\varnothing$ & $\mathrm{k}$ & MACAW SP. \\
${ }^{*} \mathrm{k}_{3}$ & $\mathrm{t}$ & $\mathrm{k}$ & THORNBUSH. \\
${ }^{*} \mathrm{p}_{1}$ & $\varnothing$ & $\mathrm{p}$ & ARMPIT, BLACK, CURASSOW, LANGUAGE, PATH, PAYMENT... \\
${ }^{*} \mathrm{p}_{2}$ & $\mathrm{w}$ & $\mathrm{p}$ & FISH. \\
${ }^{*} \mathrm{p}_{3}$ & $\phi$ & $\mathrm{p}$ & ELBOW. \\
${ }^{*} \mathrm{p}_{4}$ & $(\mathrm{~h}) \mathrm{p}$ & $\mathrm{p}$ & BIRD SP. 3. \\
\hline
\end{tabular}

The simplest of all is ${ }^{*} \mathrm{k}_{1}$, an identity $(\mathrm{k}: \mathrm{k})$ correspondence, immediately reconstructible as *k (e.g., ANT SP: M kuki, W kuki). It shows that this consonant was very stable in this branch: no significant changes occurred in its pronunciation or distribution. As for ${ }^{*} k_{2}$ and ${ }^{*} k_{3}$, they are clearly exceptional cases, possibly involving non-cognates or the result of partial analogy (see the corresponding examples in the Appendix).

The main correspondence reconstructible as ${ }^{*} p$ is ${ }^{*} p_{1}$. Note that it is not an identity $(p: p)$ correspondence, which, since Mawayana does not have a distinctive $p$, is to be expected. In fact, ${ }^{*} p_{1}$ shows that Proto-Pidjanan ${ }^{*} p$ was simply lost in all positions in Mawayana. The ${ }^{*} p_{2}$ example FISH (M kuwi, W kupai) suggests lenition: PP $* p>* b>* \beta>\varnothing .{ }^{10}$ The examples below illustrate these changes that gave rise to ${ }^{*} p_{1}$ and ${ }^{*} p_{2}$ (note $6 e-h$, where $p$-loss interacts with Mawayana diphthong reduction, $6 \mathrm{~g}$, with a-to-e raising, and 6h, with one of the few cases of Mawayana o; see Sec. 5.1.1).

(6) Examples of $p$-loss in Mawayana
a. BLACK: *pudi > M udi, W pudi
b. CURASSOW: * pawisi > M awisi, W pawiji
c. PERSON: * pidana $>M$ die(:), W pidan, pidana
d. BLOW: *pu:ta $>$ M ut[[a], W pu:ta
e. PATH: *dinapu $>M$ dinu, $W$ dinapu
$(*$ dinapu $>*$ dinaßu $>*$ dinau $>M *$ dinu $)$
f. ARMPIT: *kisapu > M ke:su, W kifapu
(*kisapu $>{ }^{*}$ kisaßu $>{ }^{*}$ kisau $>$ M ke:su)
g. FISH: *kupaił > M kuwi, W kupai
(*kupaí $>{ }^{*}$ kußai $>$ M kuwi)
h. MONKEY SP. 3: * puwati >M ot $\int \dot{t}, \mathrm{~W}$ puwati
(* puwati $>$ * puoti $>M$ ot $\left.\int \dot{t} / \mathrm{utf} \dot{\mathrm{f}} /\right)$

\footnotetext{
${ }^{10}$ One additional supporting piece of evidence for lenition is the occurrence, in a $\mathrm{M}_{1}$ example, of an apparently optional w. So BLACK (PP * pudi) is attested in this source as both udi-re and wudi-re. However, since w is phonemic in Mawayana, the lenited version of PP * $p$ was probably not ${ }^{*} w$, which would have created confusion with pre-existing *w (e.g., in minimal pairs like the prefixes *pa- '3 refl.' and *wa- ' 1 pl.', the sources of the corresponding Wapishana prefixes in Table 17), but something like $* \beta$.
} 
The only remaining correspondence, ${ }^{*} \mathrm{p}_{3}$, is obviously irregular: its only example, ELBOW (M фat $\int u r i, W$ paturi), is also the only example with a bilabial fricative $[\phi]$ in the available Mawayana data. Since the neighboring Waiwai language does have a distinctive $/ \phi /$, found also in the word for 'elbow' (Waiwai aфoresi), it seems best to ascribe this one instance of Mawayana [ $\phi]$ to Waiwai influence. Given the Wapishana cognate, ${ }^{*} p$ is reconstructed also in this case.

\subsubsection{Correspondences Involving Alveopalatal Stops, Affricates, and Fricatives}

Let us now consider the more numerous and complicated correspondences involving the alveolar consonant $t$, all listed in Table 9 below (except for those that involve the voiced stops $d$ and d; see Sec. 5.2.3).

Table 9: Correspondences involving t in Pidjanan languages.

\begin{tabular}{|c|c|c|c|}
\hline PP & MAWAYANA & WAPISHANA & EXAMPLES \\
\hline$*_{\mathrm{t}_{1}}$ & $\mathrm{t}$ & $\mathrm{t}$ & BAT, HIT, OLD MAN. \\
\hline${ }^{*} \mathrm{t}_{2}$ & $\mathrm{t}$ & $\mathrm{s}$ & MONKEY SP. 2, MEDICINE, MOSQUITO, OPPOSUM, TOBACCO... \\
\hline${ }^{*} \mathrm{t}_{3}$ & $\mathrm{t}$ & t & FISH SP. 2, PECCARY SP. 2, TOUCAN, TRUMPETER. \\
\hline${ }^{*} \mathrm{t}_{4}$ & $\mathrm{t}$ & $z$ & SWEET POTATO \\
\hline${ }^{*} \mathrm{t}_{5}$ & $\mathrm{~s}$ & $\mathrm{t}$ & BUTTERFLY, SEAT, SHOULDER/ARM. \\
\hline$*^{*} \mathrm{t}_{6}$ & t & $\mathrm{t}$ & BIRD, BLOW, CAIMAN, ELBOW, GIVE, SAND, TREE/WOOD... \\
\hline${ }^{*} \mathrm{t}_{7}$ & $\int$ & $\mathrm{t}$ & LEG/SHIN, FIRE, WITH. \\
\hline
\end{tabular}

Curiously, the best candidate for reconstruction as $*_{t}$, the identity correspondence ${ }^{*} t_{1}$, has only three examples, BAT (M tamariwa, W tamariu), HIT (M rita, W zuPita), and OLD MAN (M taurinu, $W$ tinarinau), in all 149 cognate sets. This is surprising, since alveopalatal stops are often among the most frequent consonants in phoneme inventories cross-linguistically. One is thus led to consider the correspondences with the most examples, ${ }^{*} t_{2}$ ( 6 examples) and ${ }^{*} t_{6}$ (13 examples), as more likely candidates for $*_{t}$ (with $* t_{1}$ being perhaps a special case, occurring, e.g., word- or morpheme- initially when the following vowel is *a; see the Appendix). The actual examples suggest that $*^{*} t_{6}(7 a-d)$ and ${ }^{*} \mathrm{t}_{2}$ (7e-h) contrast (cf. $7 \mathrm{a}$ and $7 \mathrm{~h}, 7 \mathrm{~b}$ and $7 \mathrm{~g}, 7 \mathrm{c}$ and $7 \mathrm{f}, 7 \mathrm{~d}$ and $7 \mathrm{e}$ ). But which one is to be reconstructed as ${ }^{*} \mathrm{t}$ ? Judging by reflexes outside of Pidjanan, ${ }^{*} \mathrm{t}_{6}$ is the best candidate, in that it is usually $\mathrm{t}$ (Bahuana haturi, aturi 'caiman', atamina 'tree'; RAMíREZ, 1992, p. 21-23), while * $t_{2}$ is not (Achagua te:ma, Baniwa je:ma 'tobacco'; RAMíREZ, 2001, p.755). Therefore, $*_{t_{6}}$ is here reconstructed as $*_{t}$ (with $*_{t_{1}}$ being also $*$ t word-initially before $\left.{ }^{*} \mathrm{a}\right)$, and ${ }^{*} \mathrm{t}_{2}$, given its reflexes ( $\mathrm{M}$ and $\mathrm{W} \mathrm{s}$ ), as $*_{\mathrm{t}}$. According to this scenario, $\mathrm{PP} *_{\mathrm{t}}>\mathrm{M} \mathrm{t}$ and $\mathrm{PP} *_{\mathrm{ts}}>\mathrm{M} \mathrm{t}$ in most environments. Obviously, ${ }^{*} \mathrm{t}>\mathrm{t}$ must have preceded $*_{\mathrm{ts}}$ $>t$, or else all PP *ts's would also have become present day t's.

(7) Examples of ${ }^{*} t_{6}(=* t ; 7 a-d)$ and ${ }^{*} t_{2}(=* t ; ; 7 e-g)$
a. TREE/WOOD: *atamina $>M$ atfamina, $W$ atamin, atamini
b. CAIMAN SP.: *aturi $>M$ atfuri, $W$ aturi
c. BIRD: *kutipira > M kutfisa, W kutipiza
d. TOAD SP.: *tururuba $>M$ tfururuba, W tururuba
e. TOBACCO: *tsu:ma > M tuma, $W$ su:ma
f. MONKEY SP. 2: *tsibirir > M tíbirit, W sibirit
g. ELECTRIC EEL: *katsumi > M katumi, W kasumi
h. OPOSSUM SP.: * wa:tsa > M wata, W wa:sa 
Note that the above examples (and the others in the Appendix) do not show $*_{t}$ or $*_{\text {ts }}$ adjacent to $*_{\mathrm{i}}$. Two correspondences could fill this gap: $*_{t_{7}}(8 \mathrm{a}-\mathrm{c})$ and ${ }^{*} \mathrm{t}_{5}(8 \mathrm{~h}-\mathrm{j})$. Note that their examples either have a permanent adjacent *i ( 8 a FIRE), or are frequently close to one ( $8 b-c, h-j ;$ the Mawayana third-person prefix ri(:)- indicates a possible i-initial stem, whence the initial *(i) in the protoform). But they, and also ${ }^{2} t_{3}(8 d-g)$, seem to contrast with each other; $c f .8 a$ and d; $8 b / 8 c$, $8 \mathrm{f}$, and $8 \mathrm{i}$. They are here ascribed to the proto-segments whose reflexes are most similar to theirs (i.e., ${ }^{*} \mathrm{t}_{7}={ }^{*} \mathrm{t}$, as $\int \mathrm{t} \mathrm{t}$ is most similar to $\mathrm{t}: \mathrm{t}={ }^{*} \mathrm{t}$, and ${ }^{*} \mathrm{t}_{5}={ }^{*} \mathrm{t}$, as $\mathrm{s}: \mathrm{t}$ is most similar to $\mathrm{t}: \mathrm{s}={ }^{*} \mathrm{t}$ ). For ${ }^{*} t_{3}$, a new proto-segment is necessary; ${ }^{*} t$ is proposed here. In other words, we reconstruct here a new alveopalatal affricate $\left({ }^{*} t\right.$, from $\left.*^{*} t_{3}\right)$ and two palatalized allophones, of $*_{t}\left(\right.$ from $\left.* t_{7}\right)$ and $*_{t s}$ (from $*_{5}$ ), found in the vicinity of $*_{i}$ ( $7 \mathrm{~h}$ tsamatsama being an exception, probably motivated by sound symbolism; it is apparently also reduplicated).

(8) Examples of ${ }^{*} \mathrm{t}\left({ }^{*} \mathrm{t}_{3} ; 8 \mathrm{~d}-\mathrm{g}\right)$, and palatalized allophones of ${ }^{*} \mathrm{t}\left({ }^{*} \mathrm{t}_{7} ; 8 \mathrm{a}-\mathrm{c}\right)$ and ${ }^{*} \mathrm{ts}_{\mathrm{s}}\left({ }^{*} \mathrm{t}_{5} ; 8 \mathrm{~h}-\mathrm{j}\right)$.
a. FIRE: *tikari > M jikari, $\mathrm{W}$ tikazi
b. LEG/SHIN: *(i)taba > M ri:-Jaba, W i-taba-?u
c. WITH: *(i)tima $>M$ ri-jima, W i-tima
d. FISH SP. 2: *atfimara $>M$ atimara, W atfimara
e. TRUMPETER: *namVtfi $>M$ namiti, $W$ namatfi
f. TOUCAN SP.: *ta:kui > M takwe, W ta:kui
g. PECCARY SP. 2: *Citfa > M rita, W bitfi, bitfa
h. BUTTERFLY: *tsamatsama $>M$ samasama, $W$ tamtam
i. SEAT: *(i)tsaba $>M$ ri:?-isaba, W i-taba
j. SHOULDER / ARM: *(i)tsawada > M ri:-sawada, W i-tawada

The remaining correspondences, ${ }^{*} \mathrm{t}_{4}$ (SWEET POTATO: $\mathrm{M}$ kati, $\mathrm{W}$ ka:zit:) and ${ }^{*} \mathrm{t}_{8}$ (THORNBUSH: M tawist, $\mathrm{W}$ kawizi $)$ ), are clearly irregular: ${ }^{*} \mathrm{t}_{8}$ was probably influenced by some other word, and ${ }^{*} t_{4}$ was probably more complicated, with perhaps one extra syllable. For further details, see the corresponding examples in the Appendix.

Given the frequent historical connections between ${ }^{*} t$ and alveopalatal fricatives and affricates, let us now take into account the remaining correspondences involving the latter two sound classes, as listed in Table 10 below.

Table 10: All correspondences involving only fricatives and affricates in Pidjanan languages.

\begin{tabular}{|c|c|c|l|}
\hline PP & MAWAYANA & WAPISHANA & EXAMPLES \\
\hline${ }^{*} s_{1}$ & $\mathrm{~s}$ & $\mathrm{~s}$ & FLOWER, BANANA, IGUANA. \\
${ }^{*} \mathrm{~s}_{2}$ & $\mathrm{~s}$ & $\int$ & ARMPIT, BEADS, CAPYBARA, CURASSOW, DEER SP, SMOKE... \\
${ }^{*} \mathrm{~s}_{3}$ & $\mathrm{~s}$ & $\mathrm{~s}$ & BANANA, BIRD, MANIOC, MOON, PET, RED, THORNBUSH... \\
${ }^{*} \mathrm{~s}_{4}$ & $\varnothing$ & $\mathrm{s}$ & SPIDER. \\
${ }^{*} \mathrm{~s}_{5}$ & $\int$ & $\mathrm{s}$ & SMALL. \\
${ }^{*} \int_{1}$ & $\int$ & $\int$ & HAIR. \\
${ }^{*} \int_{2}$ & $\int$ & $\varnothing$ & GRANDMOTHER. \\
${ }^{*} \mathrm{t}_{1}$ & $\mathrm{t}$ & $\mathrm{t}$ & MONKEY SP 4. \\
\hline
\end{tabular}

The best candidate for immediate reconstruction as *s is, of course, the identity correspondence ${ }^{*} s_{1}$ (9a-c; note the apparent reduplication in $\left.9 a\right)$. As in the case of ${ }^{*} t_{1}$ above, however, ${ }^{*} s_{1}$ has too few examples for a fricative that is usually much more frequent in phonemic 
inventories; in addition, it appears only word-initially, followed by * $\dot{i}$ or $* u$. Looking at ${ }^{*} s_{2}$, we see that it is in complementary distribution with * $s_{1}$ (it occurs near *a or *i, or, word-medially, near *u); it can thus be also reconstructed as *s.

(9) Examples of *s: * $s_{1}(9 a-c)$ and $*_{s_{2}}(9 d-h)$
a. FLOWER: *siwi > M ri-siwi, W i-su:su
(*siwi-siwit > *siwsiw > W su:su)
b. BANANA: *si:ził > M sisti-ba, $W$ sì:zi
c. IGUANA: * suwana > M suwana-da, W suwan
d. CAPYBARA: *kasu > M kasu, W kaJu
e. TUCUMÃ PALM: *sawara > M sawara, W Jawara-i
f. SMOKE: *isa- $>M$ ise-si, $W$ ifa-n
g. COCKROACH: *basarawa > M basarawa, W bafarau
h. CURASSOW: *pawisi > M awisi, W pawifi

The next correspondence, ${ }^{*} s_{3}$, is a little more complicated. It is a significant correspondence (11 examples in the available comparative data). It occurs word-internally, next to * $\dot{*}(10 a-d)$; it is thus in complementary distribution with ${ }^{*} \mathrm{~s}_{1} /{ }^{*} \mathrm{~s}_{2}$ and can be reconstructed as ${ }^{*} s$ to fill the last gap in its distribution (see, e.g., 9b/10b BANANA, with both word-initial and word-internal *s). However, it is also in complementary distribution with ${ }^{*} r_{2}$ in Sec. 5.2 .4 below, reconstructed as ${ }^{*} r$. The reflexes of ${ }^{*} s_{3}$ are just as compatible with *s and they are with *r. For now, let us keep * ${ }^{*}{ }_{3}$ as its most likely phonetic realization, *z. But is this *z an allophone of *s, or of *r?

(10) Examples of * $s_{3}$, compared with Bahuana (B) data from Ramírez (1991).
a. BIRD: *kutipiza > M kutfisa, W kutipiza
(B kutizą)
b. BANANA: * ${ }^{*} \dot{i}: z \dot{\dagger}>\mathrm{M}$ sisi-ba, $\mathrm{W}$ si:z̨it
(B surua)
c. MOON: *kaiził > M kizit, W kaiził
$(\text { B kaizit })^{11}$
d. FISH SP. 3: *kurizi > M kurisi, W kuriził
(B kuririt)

Phonetics supports * r. After all, if *s were to be chosen as the source, then one would have to admit a change ${ }^{*}>W_{z}$ in intervocalic position. The retroflection can be explained via assimilation to the central vowel $*_{\dot{i}}$, but not the voicing. Even though, cross-linguistically, intervocalic voicing is quite frequent, there is not much evidence for it elsewhere in Wapishana. Except for a few irregularities, voiceless consonants tended to remain voiceless (cf. the $*_{s}>\int$ change implied by ${ }^{*} s_{2}$ in $\left.9 d-h\right)$. On the other hand, a look at non-Pidjanan cognates supports both * $r$ and ${ }^{*}$ s. Looking at the Bahuana data, we see cases of $r(10 b, d)$, suggesting a tap $\left({ }^{*} r\right)$, and cases ofz $(10 a$, c), suggesting a fricative $\left({ }^{*} s\right)$. It is as if an earlier (pre-Proto-Pidjanan) distinction between ${ }^{*} r$ and ${ }^{*} s$ was neutralized to ${ }^{*} z$ in word-internal position, adjacent to $*_{\dot{.} .}{ }^{12}$ Taking all that into account, we propose (somewhat arbitrarily) to assign ${ }^{*} s_{3}\left({ }^{*} z\right)$ to ${ }^{*}$, including cases that may later turn out to be from (PP or pre-PP) *s.

\footnotetext{
${ }^{11}$ Ramírez (1992) used a capital R to represent the second, non-palatoalveolar Bahuana rhotic, which he described as a posterior velar tap. Later, Ramírez (2001) used IPA $\uparrow$ (retroflex approximant) for this sound, and also for the Wapishana rhoticized retroflex fricative here transcribed as z i.e., Ramírez apparently saw both the Bahuana and the Wapishana sounds as the same. For this reason, the same symbol z is used here also for the Bahuana data.

${ }^{12}$ Ramírez (1992, p. 16) mentions, for Bahuana, a similar neutralization of $r(=r)$ and $R(=z)$ to $z$ in a similar environment: between two i's (e.g., /nit-rit/ = [nizit] 'big').
} 
The remaining correspondences, ${ }^{*} \mathrm{~s}_{4},{ }^{*} \mathrm{~s}_{5}, * \int_{1}, * \int_{2}$, and $*_{\mathrm{t}_{1}}$, are all idiosyncratic cases. There is no evidence for a separate $* \int\left(\int_{1}\right.$ and $* \int_{2}$, and also $*_{5}$, probably result from $*_{s}$ in palatal environments), and ${ }^{*} s_{4}$ and ${ }^{*} t_{1}$ suggest possible external influence. For further details, see the corresponding examples in the Appendix.

\subsubsection{Correspondences Involving Voiced Implosives}

Turning now to implosives, i.e. the remaining stops, let us consider the corresponences listed in Table 11 below.

Table 11: Correspondences involving voiced implosives (and d) in Pidjanan languages

\begin{tabular}{|l|c|c|l|}
\hline PP & MAWAYANA & WAPISHANA & EXAMPLES \\
\hline$* b_{1}$ & $\mathrm{~b}$ & $\mathrm{~b}$ & AÇAÍ, BEE/HONEY, LEAF, MONKEY SP 1, STONE, TONGUE... \\
$* \mathrm{~b}_{2}$ & $\mathrm{~b}$ & $\mathrm{p}$ & CAJÁ, PAPAYA. \\
$* \mathrm{~b}_{3}$ & $\mathrm{r}$ & $\mathrm{b}$ & PECCARY SP 2. \\
$* \mathrm{~d}_{1}$ & $\mathrm{~d}$ & $\mathrm{~d}$ & ACOUCHY, BREAST, KNEE, PATH, SKIN/BARK, SALT, TAPIR... \\
$* \mathrm{~d}_{2}$ & $\mathrm{~d}^{j}$ & $\mathrm{~d}$ & PERSON, SMALL. \\
$* \mathrm{~d}_{3}$ & $\mathrm{t}$ & $\mathrm{d}$ & BELT, NOSE, THIN. \\
$* \mathrm{~d}_{1}$ & $\mathrm{t}$ & $\mathrm{d}$ & COMB, FATHER, INAJÁ, MOTHER. \\
$* \mathrm{~d}_{1}{ }_{1}$ & $\mathrm{j}$ & $\mathrm{d}^{j}$ & BURITI. \\
$* \mathrm{~d}^{j}{ }_{2}$ & $\mathrm{~d}^{j}$ & $\mathrm{z}$ & CLAW/NAIL. \\
$* \mathrm{~d}^{j}{ }_{3}$ & $\mathrm{~d}$ & $\mathrm{t}$ & COATI. \\
\hline
\end{tabular}

First of all, ${ }^{*} b_{1}$ and ${ }^{*} d_{1}$ are identity correspondences immediately reconstructible as $* b$ and $* d$. Most of the others appear to reflect idiosyncratic changes: ${ }^{*} d_{2}$ has two examples involving palatalization due to a preceding *i (in Mawayana, lost in PERSON: $M{ }^{*} d^{j} \mathrm{e}(:), \mathrm{W}$ pidana, but not in

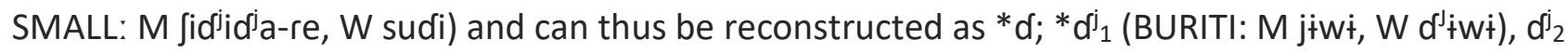
(CLAW/ NAIL: M bad ${ }^{\mathrm{ji}} \mathrm{i}, \mathrm{W}$ bazi) and ${ }^{*} \mathrm{~d}_{3}{ }_{3}$ (COATI: M kadi, W kuatfi) are the best candidates for a ProtoPidjanan $*{ }^{j}{ }^{j}\left({ }^{*}{ }^{j}{ }_{1}\right.$ word-initially, followed by $*_{\dot{i}},{ }^{*} d^{j}{ }_{2}$ and $* d^{j_{3}}$ word-medially, ${ }^{*} d_{j}{ }^{2}$ follwed by $* i$ and

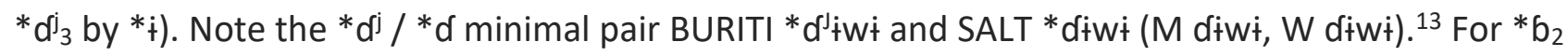
and ${ }^{*} b_{3}$, see the corresponding examples in the Appendix.

The remaining two correspondences, ${ }^{*} d_{3}$ and ${ }^{*} d_{1}$, are more consequential, since they seem to suggest the reconstruction of a distinction between an implosive $* d$ and a non-implosive $* d$ to Proto-Pidjanan.

(11) Examples of * $d 3(11 a-c)$ and *d1 $(11 d-g)$.
a. BELT: *antawi $>M$ rantawi-da, W za:dawi
b. NOSE: *(i)diba > M ri-tiba, W i-idiba
c. THIN: *miCa- $>\mathrm{M}$ meta-da, $\mathrm{W}$ mida- $\mathrm{i} \dot{\mathrm{t}}$
d. COMB: *mauCi $>M$ muti-ba, $\mathrm{W}$ maudi
e. FATHER: ${ }^{*} \mathrm{Ca}>\mathrm{M}$ ri-ta, $\mathrm{W}$ i-da-ri
f. MOTHER: *Ca-ru $>$ M ri:-taru, W i-daru
g. INAJÁ PALM: * puk- > M ukati, W pukuridi

\footnotetext{
13 Despite the minimal pair, PP * dj may eventually derive from (pre-PP) palatalization of an aveopalatal stop by a preceding *i-compare BURITI: M jiwi, W d'łwi with closely related Bahuana iciwi, itiwi 'buriti' (RAMÍREZ, 1992, p.7, p. 115 , p. 117).
} 
Interestingly, most cases of $* d_{3}$ and $* d_{1}$ have an adjacent $* i$, which suggests reconstruction as $* d$ (the cases of * $d$ examined thus far do not occur in this environment). There are, however, a few problems: PERSON * pidana (M dje(:), W pidana) seems to contrast with THIN (11c), and FATHER and MOTHER (11e-f) do not have adjacent *i's. The former case does not seem enough to warrant the reconstruction of a new proto-segment, but it is also difficult to choose between already available ones $\left(* d, *^{j}\right.$ and $*^{t}$ would all imply different reflexes). It seems best to signal this uncertainty by adding an undetermined consonant ${ }^{*} \mathrm{C}$ to the reconstruction ( ${ }^{*}$ miCa-). For NOSE (11b), * $d$ is reconstructed, with the adjacent *i's as the conditioning environment; for BELT (11a), $*_{n t}$ is reconstructed as the only example of a Proto-Pidjanan nasal cluster in the comparative corpus. As for FATHER and MOTHER (11e-f), there cleary is a common morpheme ( $\mathrm{M}$ ta, $\mathrm{W}$ da), so that both cognate sets are effectively the same. There is therefore only one example of $t: d$ not adjacent to a palatalizing $* \mathrm{i}$, i.e., the reconstruction of a PP $* d$ would have little basis. Taking also into account that the Wapishana $d / d$ distinction is somewhat problematic (W $d$ outnumbers $d$ by a ratio of $6: 1$, and there are cases of variation), it seems best to reconstruct only an undetermined consonant ${ }^{*} \mathrm{C}$, while waiting for more evidence on the history of FATHER and MOTHER. For COMB (11d), an undetermined ${ }^{*} C$ also seems to be better $\left({ }^{*} d\right.$ would not be possible, since ${ }^{*} d_{3}$ in the same environment has already been reconstructed as $* d$; see the contrast between $* d_{3}$ in NOSE $11 b$ and COMB). It is hoped that further research will shed some light on the nature of these ${ }^{*} C^{\prime} s$ (note that ${ }^{*} C^{\prime}$ 's reflected as $* d_{3}$, like $11 c$, are probably not the same as ${ }^{*} C^{\prime}$ 's reflected as ${ }^{*} d_{1}$, like $\left.11 d-f\right)$.

\subsubsection{Correspondences Involving Rhotics}

In Table 12 below, we can see all Pidjanan correspondences involving r. Of these correspondences, ${ }^{*} r_{1}$ is an identity and thus the best candidate for immediate reconstruction as ${ }^{*}$. It is also very frequent, occurring in $28 \%$ of all cognate sets (see, e.g., 12a-g, i).

Table 12: Correspondences involving rhotics in Pidjanan languages

\begin{tabular}{|c|c|c|l|}
\hline PP & MAWAYANA & WAPISHANA & EXAMPLES \\
\hline${ }^{*} r_{1}$ & $r$ & $r$ & ACOUCHY, DEER SP, DRY, FAN, INGÁ, KNEE, LANGUAGE... \\
${ }^{*} r_{2}$ & $r$ & $r$ & BELT, CAJÁ, CORN, FIRE, FISH SP 1, SKY, TERMITE, WOMAN... \\
$*_{r_{3}}$ & $\mathrm{r}$ & $\varnothing$ & FROM. \\
$*_{r_{4}}$ & $\varnothing$ & $r$ & BIRD SP 2, BITE. \\
$*_{r_{5}}$ & $\mathrm{r}$ & $\mathrm{n}$ & TICK. \\
\hline
\end{tabular}

The next one is $*_{2}$, occurring in a robust 15 ( $10 \%$ of all) cognate sets (see, e.g., $12 \mathrm{~h}-\mathrm{I}$ ). In several pairs, ${ }^{*} r_{2}$ and ${ }^{*} r_{1}$ occur seemingly in contrast, in the same environments (e.g., $12 \mathrm{~g}$ and $12 \mathrm{k}-\mathrm{l}, 12 \mathrm{c}$ and $12 \mathrm{i}, 12 \mathrm{f}$ and $12 \mathrm{j}, 12 \mathrm{~b} / 12 \mathrm{e}$ and $12 \mathrm{~h}$ ), which indicates that they cannot have the same reconstruction. Given the retroflex quality of $W z_{v}$ the best reconstruction for $*_{r_{2}}$ would be a retroflex $\operatorname{tap}\left({ }^{*} r\right)$. For an additional allophone of ${ }^{*}$, see ${ }^{*} s_{3}$ in Sec. 5.2.2 above.

(12) Examples of Pidjanan rhotics.
a. ACOUCHY: *aduri $>M$ aduri, $\mathrm{W}$ aduri
h. WOMAN: *rina $>M$ rina-ru, $W$ zina
b. WIND: *awari $>M$ awari, W awari
i. EARTHWORM: * pararu $>M$ araru, $W$ pazaru
c. LANGUAGE: *para $>\mathrm{M}$ ara, $\mathrm{W}$ para-da
j. CORN: *mariki $>M$ mariki, $\mathrm{W}$ maziki
d. KNEE: *kuduru > M kuduru, W kuduru
k. HIT: *ruPita > M rita, W žuPita 
e. MURUMURU: *biri > M birit, W birit

f. BAT: *tamariwa $>M$ tamariwa, $\mathrm{W}$ tamariu

g. MONKEY SP. 1: *ru:mu > M rumu, W ru:mi

I. CAJÁ: *ru:ba > M ruba, W żu:p

The remaining rhotic correspondences all appear irregular: ${ }^{*}{ }_{55}$, for instance, contains only one example with what seems to be the only case of metathesis in the available comparative data; ${ }^{*}{ }_{3}$, again with only one example, occurs at morpheme boundaries with an ablative morpheme ${ }^{*}(r)$ iki whose diachronic evolution is poorly understood; and ${ }^{*} r_{4}$ has two examples of what looks like irregular ${ }^{*}$ l loss in Mawayana (BITE: M autfa, W aru:ta, BIRD SP. 2: M ma:ti, $W$ marati; cf. cases in which, in the same environmentsm PP * $r$ is not lost in Mawayana, like BIRD SP. 1: M anaru, W anarau, PARROT SP.: M waru, W waru, or LANGUAGE: M ara, W para-da, FISH SP. 2: M atimara, W atfimara). Thus, for ${ }^{*} r_{3},{ }^{*} r_{4}$, and ${ }^{*} r_{5}$, partial or total non-cognacy cannot be excluded. To mark this uncertainty, a parenthetical * $(r)$ is reconstructed.

\subsubsection{Correspondences Involving Nasals}

Table 13 below lists all correspondences involving nasal consonants found in the available data.

Table 13: Correspondences involving nasal consonants in Pidjanan languages

\begin{tabular}{|c|c|c|l|}
\hline PP & MAWAYANA & WAPISHANA & EXAMPLES \\
\hline${ }^{*} \mathrm{~m} 1$ & $\mathrm{~m}$ & $\mathrm{~m}$ & BEE/HONEY, BRAZIL NUT, DRY, INGÁ, SUN, TREE/WOOD... \\
${ }^{*} \mathrm{n} 1$ & $\mathrm{n}$ & $\mathrm{n}$ & AS, BRAZIL NUT, LEAF, PAYMENT, SHAMAN, SIEVE, SONG... \\
${ }^{*} \mathrm{n} 2$ & $\varnothing$ & $\mathrm{n}$ & BREAST, EAT, HEART, HOUSE, PERSON, ROPE, TONGUE... \\
${ }^{*} \mathrm{n} 3$ & $\mathrm{n}$ & $\varnothing$ & I, BELT, LOUSE. \\
${ }^{*} \mathrm{n} 4$ & $\mathrm{n}$ & $\mathrm{j}$ & TONGUE, HEART. \\
${ }^{*} \mathrm{n} 5$ & $\mathrm{n}$ & $\mathrm{r}$ & TICK. \\
\hline
\end{tabular}

The simplest correspondences are ${ }^{*} \mathrm{~m}_{1}$ and ${ }^{*} \mathrm{n}_{1}$, indentity cases with multiple examples; they can be immediately reconstructed as *m and *n (e.g., SUN: M kamu, W kamu:, BRAZIL NUT: M mini, W minat, LEAF: $M$ anaba, $W$ anaba, AS: $M$ ni, $W$ ni:, etc.). The next correspondence, ${ }^{*} n_{2}$, shows cases of loss in Mawayana, as exemplified below. Notice that it occurs most often with an adjacent $*_{i}$ (13a-d, $k-1)$, but there are exceptions (13e-g, i-j), including one, MEAT FOOD, that contrasts with * $n_{1}$ as part of an analogous pair with SONG (13g-h); cf. also BREAST (13i), which has $M d i$ in the possessed form (e.g., $n \dot{t}-d \dot{d}$ 'my breast'). This contrast implies that ${ }^{*} n_{1}$ and ${ }^{*} n_{2}$ must have different reconstructions. Since ${ }^{*} n_{1}$ is already ${ }^{*} n$, and given the often palatal environments where ${ }^{*} n_{2}$ occurs, we propose to reconstruct ${ }^{*} n_{2}$ as ${ }^{*} n$, a consonant lost in Mawayana. Note that the ${ }^{*} n_{4}$ example, TONGUE (13d), can also be explained via n-loss: ${ }^{*} n_{4}$ can thus also be reconstructed as ${ }^{*}$ n. Note that *n-loss often, but not always, nasalizes adjacent vowels, sometimes leaving behind a palatal glide j, realized as [n] (compare 13a-g and 13i-I). When nasalization happens, diphthong reduction does not (compare $13 \mathrm{~b}$ and $13 \mathrm{k}$ ). In Wapishana, *n usually becomes $\mathrm{n}$; the only exception, HEART (13e), is surprising (cf. 13d; see HEART in the Appendix). 
(13) Examples of $\mathrm{n}$-loss in Mawayana.
a. EAT: *nika > M ĩka, W nika
b. HOUSE: * pani > M aĩ-, W pani-
c. ROPE: *inupi > M jũwi, $W$ inupi
d. TONGUE: *ninuba > M jũjũba, $W$ ninuba
(* pani- > *ani- > M aĩ-)
(*inupi > *i.ũ.i > M jũwi [nũwi])
e. HEART: *nikinija > M îkîjã, W nikini:
(*ninuba $>$ *ĩjũba $>$ jũjũba [nũnũba])

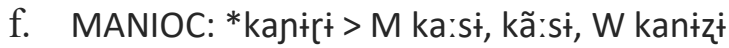
(*nikinija > *nikinija > M îkĩãa [ĩkĩnã])
g. MEAT FOOD: * wini-i $>M$ wĩ, $W$ wini-i

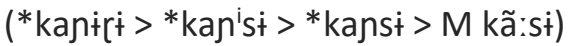
(*wini-i $>*^{*}$ wini $>*^{*}$ wĩ. $>>M$ wĩ)

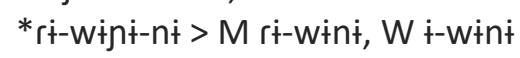

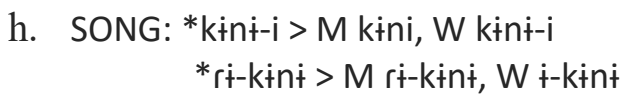

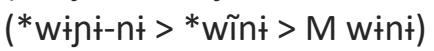
i. BREAST: *dinit $>M$ dit, $W$ dinit
j. PERSON: * pidana $>M$ die(:), W pidana
k. CHILD/EGG: *dani $>M$ de, $W$ dani
1. PARTNER: *mina- $>M$ me:-rawa, $\mathrm{W}$ mina-ida?i
(* pidana $>$ *ida: $>$ *ide: $>M$ dje(:))
(*dani $>*$ dai $>$ M de)
$\left({ }^{*}\right.$ mina $>$ *mia- $>$ M me:-)

The remaining correspondences look irregular: ${ }^{*} \mathrm{n}_{3}$ contains two cases of word-initial syllabic $\mathrm{n}$ in Mawayana without counterparts in Wapishana (I: M n.nu, W ũ-gari, LOUSE: M n.ni, W nai) and a Mawayana nasal-stop cluster corresponding to Wapishana vowel length (BELT: M rantawi-da, W za:dawi), which suggests $n$-loss with compensatory lengthening and voicing of the remaining stop in Wapishana. Since these are the only cases in the available comparative data, it is better not to make too many inferences and simply note those as irregular developments of ${ }^{*} n$. As for $*^{*} n_{5}$, its one example (TICK: M kunuriba, W kurinaba) contains what may be the only occurrence of metathesis in the available comparative data. For further details, see the Appendix.

\subsubsection{Remaining Correspondences: Approximants and Glottal Stops}

The last few consonant correspondences are listed in Table 14 . It is obvious that ${ }^{*} \mathrm{w}_{1}$, an identity correspondence, is the best candidate for immediate reconstruction as * $w$ (in, e.g., AÇAÍ: M wabu, W wabu, PAYMENT: M wina, W winipa, SALT: M diwi, W diwi).

Table 14: Correspondences involving approximants and glottal stops in Pidjanan languages

\begin{tabular}{|c|c|c|l|}
\hline PP & MAWAYANA & WAPISHANA & EXAMPLES \\
\hline${ }^{*} \mathrm{w}_{1}$ & $\mathrm{w}$ & $\mathrm{w}$ & AÇAÍ, CURASSOW, MEAT FOOD, IGUANA, PAYMENT, SALT... \\
${ }^{*} \mathrm{w}_{2}$ & $\mathrm{w}$ & $\mathrm{p} / \mathrm{b}$ & ROPE. \\
${ }^{*} \mathrm{p}_{1}$ & $\varnothing$ & $?$ & BIRD, BURN, HAND, HIT, OTHER, PAPAYA. \\
${ }^{*} \mathrm{j}_{1}$ & $\mathrm{j}$ & $\mathrm{i}$ & PAPAYA. \\
${ }^{*} \mathrm{j}_{2}$ & $\varnothing$ & $\varnothing \sim \mathrm{j}$ & KNIFE. \\
${ }^{*} \mathrm{j}_{3}$ & $\mathrm{j}$ & $\varnothing$ & HEART. \\
\hline
\end{tabular}

Likewise, $* ?_{1}$ is the best (in fact, the only) candidate for reconstructing a Proto-Pidjanan glottal stop, even though it is not an identity correspondence. It reflects ?-loss in Mawayana, with subsequent diphthong reduction or, if the two adjacent vowels were the same, fusion (e.g., HIT: M rita, W: zupita, HAND: M ki-ba, M ka?i, BIRD: M kutfisa, W kuti?iza). Note that the one ${ }^{*} \mathrm{w}_{2}$ example, ROPE (M jũwi, $W$ inu?i, inubi), includes a glottal stop and shows (dialectal?) variation within Wapishana. This variation is especially frequent when $b$ or $d$ are adjacent to the high vowels i, u (cf. W W $_{1}$ paritibi, pariti?i 'ashes', dokoridi, dokori?i 'chest', dudua, du?ua 'break', tuubuzi, tu?uzi 
'huge'). The Mawayana cognate jũwi can be readily explained if the glottal stop is reconstructed: as was the case for $* ?_{1}$, it was lost, with $M w$ resulting from the expansion of the preceding $u$ to onset position ( ${ }^{*}$ inupi $>*^{*}$ i.u. $i>{ }^{*}$ jũ.i $>M$ jũwi). Therefore, ${ }^{*} w_{2}$ is really a case of ${ }^{*} ?_{1}$ and is reconstructed as $*$ ?. ${ }^{14}$

Looking finally at the palatal glide correspondences $* \mathrm{j}_{1},{ }_{\mathrm{j}_{2}}$, and ${ }^{*} \mathrm{j}_{3}$, all three can clearly be reconstructed as *j. All three contain examples in which the Wapishana cognate shows loss of the final unstressed vowel, with the preceding glide being reduced either to the second element of a diphthong ( $*_{j_{1}}$ PAPAYA: M mabaja, W maPapai) or to vowel length ( $*_{j} j_{3}$ HEART: M ĩkĩã, W jikini:, $*_{j_{3}}$ KNIFE: $M$ mare, $W$ mari:, $\left.\dot{t}-m a r i j a-n\right)$, according to the surrounding environment: ${ }^{*} j_{2}$ when the preceding vowel is $*_{i}, *_{3}$ when it is $*_{\dot{i}}$, and $*_{j_{1}}$ when it is neither; with $\dot{i}$, a tendency to avoid a final $\mathrm{W}+\mathrm{i}$ diphthong, suggestive of the non-possessed marker $-\mathrm{i}$, may have played a role). In Mawayana, $*_{j}$ is lost only in KNIFE, for which an explanation based on a-to-e raising and diphthong reduction can be readily found (PP *marija $>*^{*}$ mari(j)e $>*^{*}$ marie $>M$ mare). Therefore, no contrast exists between $* \mathrm{j}_{1}, *_{\mathrm{j}_{2}}$, and $*_{\mathrm{j}_{3}}$, all reconstructible as $* \mathrm{j}^{15}$

\section{A Summary Description of Pidjanan Historical Phonology and Basic Morphology}

Based on the preceding discussion of the available cognate sets, the distinctive proto-segmentes (proto-phonemes) in Table 15 below are here proposed for Proto-Pidjanan.

Table 15: Proto-Pidjanan distinctive segments (phonemes)

\begin{tabular}{|c|c|c|c|c|c|c|c|c|c|c|}
\hline \multirow{3}{*}{$\begin{array}{l}\text { HIGH } \\
\text { MID }\end{array}$} & FRONT & CENTRAL & BACK & & LAB & ALV & PAL & RETR & VEL & GLOT \\
\hline & $*_{\mathrm{i}}$ & $*_{\dot{t}}$ & $* u$ & PLO & $* p$ & $*_{\mathrm{t}}$ & & & ${ }^{*} \mathrm{k}$ & $* ?$ \\
\hline & & & & IMPLC & $* b$ & $* d$ & $* d^{j}$ & & & \\
\hline \multirow[t]{5}{*}{ LOW } & & $* a$ & & AFFR & & ${ }^{*} \mathrm{ts},{ }^{*} \mathrm{t}$ & & & & \\
\hline & & & & FRIC & & $*_{s}$ & & $*_{z}$ & & \\
\hline & & gth: ${ }^{*} \mathrm{a}_{\mathrm{i}} *_{\mathrm{i}}$ & & TAP & & $*_{r}$ & & ${ }^{*} r$ & & \\
\hline & & & & NAS & $*_{\mathrm{m}}$ & $*_{n}$ & $*_{n}$ & & & \\
\hline & & & & APPR & $* w$ & & $\left(*_{j}\right)$ & & & \\
\hline
\end{tabular}

\footnotetext{
${ }^{14}$ These correspondences suggest that there should be no Mawayana glottal stops. One does find a few: ri?u, ri?unu '2 pl.' (pronoun), we?awinu '1 pl.' (pronoun), kija?a 'high', etc. They are, nevertheless, relatively few, occurring in only about 25 out of 600 morphemes in the available data, and none of them have Wapishana cognates. Considering that a frequent environment for Mawayana glottal stops was at morpheme boundaries, intervocalically (e.g., atfamina 'tree' => atfamina-?-abi 'tree sap', or Jikari 'fire' => Jikari-?-awini 'firewood'), one may wonder if this might be true, at least historically, also for the cases in which the component morphemes are not, or no longer, obvious.

${ }^{15}$ Looking at the number of examples, one is struck by how few instances of $*_{j}$ there actually are: only three. In fact, the palatal glide is quite rare in Wapishana (only about 26 out of about $1,800 \mathrm{~W}_{1}$ headwords have it). Mawayana has a more considerable number (about 45 out of 600 morphemes), but most of the five that occur in cognate sets have origins other than *j (two from *n and one from * ${ }^{*}$; ; see above). Given that some Wapishana stems alternate between having a full jV syllable and only a reduced diphthong element (e.g., for 'want, need', realis aipan [,aj.' pan] and irrealis ajapa [a.'ja.pa]), ongoing unstressed vowel loss is a plausible explanation: *[a.ja.'pan] > [aj.' pan]. In this case, no reduced trace of the original vowel has remained (unlike the final a in [a.'ja.pa] = [a'japa ${ }^{a}$; cf. Sec. 3).
} 
Table 16: Main (regular) changes from Proto-Pidjanan to Mawayana and Wapishana.

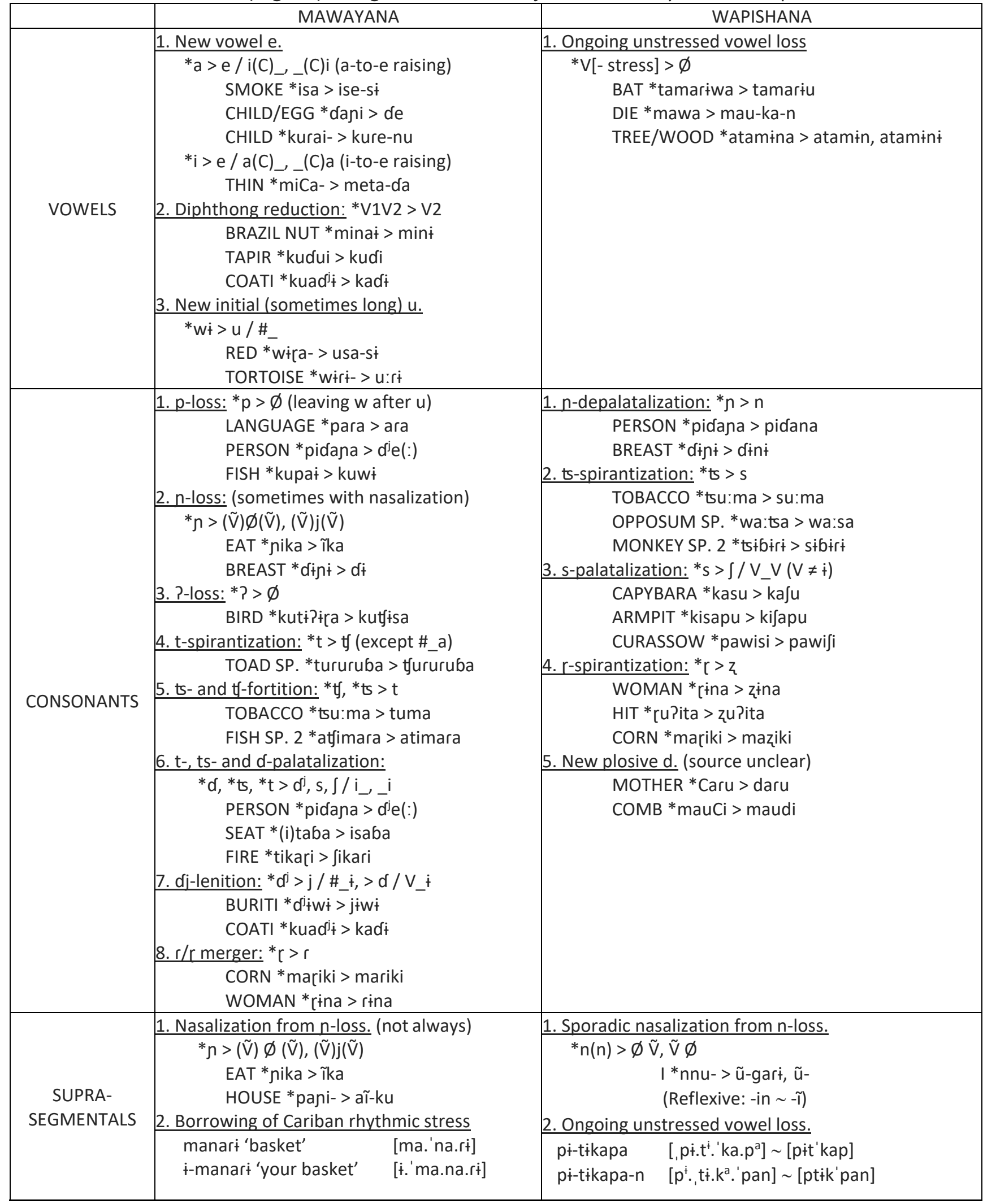

Table 16 shows that Mawayana was the innovative Pidjanan language: most of the changes happened between Proto-Pidjanan and Mawayana, while Wapishana remains for the most part still very similar to Proto-Pidjanan. 
The vowels of Proto-Pidjanan did not change very much. Other than the rise of a new mid vowel e in Mawayana (from PP *a, sometimes *i), and occasional, mostly stress-driven, vowel loss in Wapishana, nothing much happened to them.

Most non-palatoalveolar consonants did not change much either. The nasals ${ }^{*} m$ and ${ }^{*} n$ remained very much the same, except for occasional cases of loss with nasalization of neighboring vowels in Wapishana. The velar stop * $k$ also remained unchanged, as did the voiced implosives * $b$ and $* d$ and the approximants $* w$ and $*_{j}$ (except when the vowel following the approximant was lost, in which case it resyllabified with the preceding vowel, forming a diphthong). The labial and glottal stops ( ${ }^{*} p$ and ${ }^{*}$ ?) were lost in Mawayana but conserved in Wapishana.

It was in the palatoalveolar region that most of the action happened in Pidjanan history. The stop *t was conserved in Wapishana but changed to in $t$ Mawayana (except word-initially, followed by $a$, where it was conserved as $\mathrm{t}$ ); the affricate ${ }^{*} \mathrm{t}$ did not survive, becoming $\mathrm{t}$ in Wapishana and $\mathrm{s}$ in Mawayana. These two sounds were palatalized when adjacent to $*_{\mathrm{i}}$, becoming respectively $\int$ and s in Mawayana; in Wapishana, even in this environment *t was preserved and *ts was fortitioned to t. The affricate ${ }^{t} \mathrm{y}$ was conserved in Wapishana and fortitioned to in Mawayana. The palatal nasal *n was lost in Wapishana (often nasalizing neighboring vowels) and depalatalized to $n$ in Wapishana. The palatal tap ${ }^{*} r$ merged with * $r$ in Mawayana (resulting in $\left.r\right)$. In Wapishana, ${ }^{*} r$ sibilantized to z. (A few ${ }^{*} r$ may be historically derived from (pre-)PP *s surrounded by * ${ }^{*}$ 's, an environment in which ${ }^{*} r$ and *s have apparently merged; judging by the reflexes, * $r$ was realized as * [ $z]$ in this environment). The fricative *s was basically conserved in Mawayana but palatalized to $\int$ in Wapishana.

As one can see, most changes were assimilatory (palatalization, raising, etc.), with a few cases of lenition and fortition thrown in for good measure. Only very sporadically did possible cases of metathesis or haplology surface.

\subsection{Basic Proto-Pidjanan Morphology}

At this point, a full reconstruction of Proto-Pidjanan morphological markers cannot be carried out. A few aspects of the basic morphology, however, can be preliminarily approached.

The person-marking system, shown in Table 17 in the Appendix, is mostly easy to reconstruct on the basis of what has been discovered so far about Pidjanan historical phonology.

(14) Proto-Pidjanan person-marking prefixes.
a. 15
*nu- > M n-, W ũ-
b. $2 S$
*pí- $>M \dot{q}-, W$ pí-
c. 3S.MASC
$*(r) \dot{q}->M r \dot{r}-, W \dot{+}-$
d. 3S.FEM
$*(r) \mathrm{u}->\mathrm{M}, \mathrm{W}$ u-
e. 3S.COREF
*pa- $>\mathrm{M}$ a-, W pa-
f. $1 \mathrm{P}$
*wa- > M wa-, W wa-
g. $2 \mathrm{P}$
$*_{\dot{1}-}>M \dot{i}-, W$ pí-
h. $3 P$
$*_{n}$ V- $>$ M na-, W -i

Most reconstructions in (14) are straightforward. The third-person gender distinction exists only in Wapishana; Mawayana has apparently lost it (though a few lexicalized examples still remain; e.g., de-sí 'son', de-ru 'daughter'). Such remains, as well as the overwhelming evidence from outside 
of Pidjanan, warrant the reconstruction of gender distinctions to Proto-Pidjanan. The parenthetical $*(r)$ in 14c-d is based on the Mawayana masculine form, and also on overwhelming evidence from non-Pidjanan languages. It is true, however, that these * $(r)^{\prime}$ s should have survived in Wapishana, which is why their reconstruction is only tentative. Finally, $14 \mathrm{~h}$ (third-person plural) is more complicated: W nasal ĩ suggests PP *ni-, but the vowel does not agree with $M$-na. An undetermined vowel is reconstructed here, though one must admit that it is not clear that the two prefixes are actually cognate.

(15) Proto-Pidjanan person-marking suffixes.
a. $1 \mathrm{~S}$
$*$-na $>M-n a, W-n,-n a$
b. $2 S$
$*-p V>M-i, W-p,-p a$
c. 3S.MASC
$*_{-}(\mathrm{c}) \dot{\mathrm{t}}>\mathrm{M}-\mathrm{s} \dot{\mathrm{t}}, \mathrm{W}-\mathrm{z} \dot{\mathrm{t}}$
d. 3S.FEM
$*-(\mathrm{r}) \mathrm{u}>\mathrm{M}, \mathrm{W}-\mathrm{zu}$
e. $1 \mathrm{P}$
f. $2 \mathrm{P}$
*-wi $>M-w i, W$
g. $3 P$
*-wiko $>M$-wiko, $\mathrm{W}$
$*$-nu > M -nu, W -ził

The suffixes are clearly more difficult to reconstruct. First of all, because some forms are no longer attested (3S.FEM in Mawayana, though the final -ru in de-ru 'daughter', ta-ru 'mother' is probably a remnant of this suffix; and the $1 \mathrm{P}$ and 2P forms in Wapishana, apparently now replaced by full pronouns). Secondly, the vowel is not always consistent (15b). Thirdly, there are apparently non-cognate forms (15g). Still, the existence of a suffix system, used on transitive verbs to refer to the object, must be reconstructed, even when the forms no longer exist (Wapishana 15e-f; the Mawayana forms are reconstructed by default), given the overwhelming agreement of nonPidjanan languages on this topic. Further uses (the prefixes, besides marking verb subjects, are also used to mark the possessor on possessed nouns and the argument on postpositions; the suffixes also mark the subject of stative intransitive verbs) must likewise be reconstructed, even if in some cases they are no longer attested (Wapishana has apparently lost the use of the suffixes to mark the subject of stative intransitives, but Mawayana still retains it).

(16) The functions of person markers (verbs in the - $\mathrm{ni}$ ' 'realis'/'present' form).
a. $A$ and $O$ on transitives:

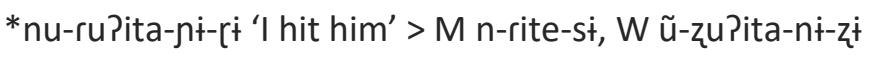
b. SA on active intransitives:
*(r)i-si?uka-ni 'he walks' > M ri-suke, W i-tjiiika-n
c. SO on stative intransitives:

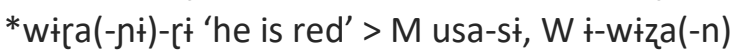
d. arguments on adpositions:
*(r)i-(i)tima 'with him' > M ri-jima, W i-tima
e. possessors on nouns:
*nu-kinit 'my song' > M n-kinit, W ũ-kini

In the realm of nominal possession, it is possible to reconstruct possession-marking suffixes zero and *-ni (17a-b); for inalienable nouns, it is possible to reconstruct a marker of non-possessed status *-i (17c; cf. also footnote 4).

(17) Nominal possession: possessed and non-possessed forms.
a. Possession marker *-ni
*wa-marija-ni 'our knife' > M wa-mare-ni, W wa-marija-n
b. Possession marker zero
*(r)i-tsaba 'his seat' > M ri?-isaba, W i-taba
c. Non-possessed status
*(i)tsaba-i 'seat' > M isabe, W taba-i 
Finally, in the realm of verbal tense-aspect-mood morphology, it is possible to reconstruct a 'realis' / 'present' marker *-ni, from which both $W-n,-n \dot{7}$ 'realis' and $M$-e 'present' (actually, the

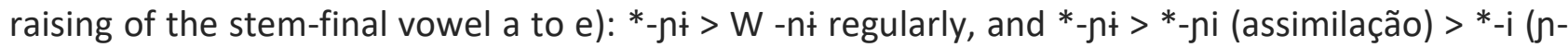
loss); *-i then raises (and/or merges with) the stem-final vowel a, leading to $\mathrm{M}$-e (see also footnote 5 above). ${ }^{16}$

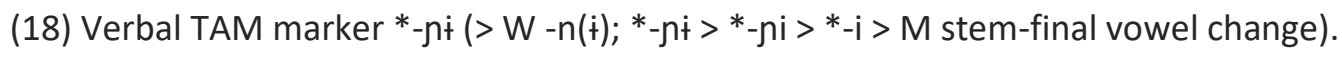

a. ${ }^{*}(r)$ i-pu:ta-ni ‘he blows' $>$ M r-utfe, W i-pu:ta-n

\section{References}

AIKHENVALD, A. Y. The Arawak language family. In Dixon, R. M. W.; Aikhenvald, A. Y. (eds.). The Amazonian languages. Cambridge: Cambridge University Press, 1999. p. 65-106.

CARLIN, E. Feeling the need: the borrowing of Cariban functional categories into Mawayana (Arawak). In Aikhenvald, A. Y.; Dixon, R. M. W. (eds.). Grammars in contact: A cross-linguistic typology. Oxford: Oxford University Press, 2006. p.313-332.

CARLIN, E. Karahpada. Arahka iwehtoponpë, Japoma inponopïhpë. [A short text, "Story of curassow sp.", in Mawayana, Tiriyó, English, and Dutch], no date.

HAYNIE, H.; BOWERN, C.; EPPS, P.; HILL, J.; MCCONVELL, P. Wanderwörter in languages of the Americas and Australia. Ampersand, vol. 1, 2014. p. 1-18.

HOWARD, C. V. Formulário dos vocabulários padrões: Questionário do Museu Nacional. 2ed. (1960), manuscrito. Universidade Federal do Rio de Janeiro (Filled in for Mawayana), 1985-1986.

KAUFMAN, T. The native languages of South America. In MOSELEY, C.; ASHER, R. E. (eds.). Atlas of the World's Languages. London: Routledge, 1994. p. 46-76.

MEIRA, S. Rythmic stress in Tiriyó (Cariban). International Journal of American Linguistics, vol. 64, n. 4, p. 352-378, 1998.

MELLO, A. Estudo histórico da família lingüística Tupi-Guarani: aspectos fonológicos e lexicais. 2000. Ph.D. dissertation. Universidade Federal de Santa Catarina (UFSC), Florianópolis (Brasil), 2000.

MELVILLE, C.; TRACY, F. V.; WILLIAMS, O. International Dictionary Series, filled in for Wapishana, 2007. Downloaded on Oct. 30, 2007, from <http://ids.clld.org/contributions/266>.

PAYNE, D. L. A classification of Maipuran (Arawakan) languages based on shared lexical retentions. In Derbsyhire, D. C.; Pullum, G. K. Handbook of Amazonian Languages. Vol. 3. Berlin, New York: Mouton de Gruyter, 1991. p. 357-499.

RAMÍREZ, H. Le bahuana: une nouvelle langue de la famille arawak. Chantiers Amerindia. Amerindia vol. 17, Supplement 1, Paris, 1992.

RAMÍREZ, H. Línguas Arawak da Amazônia setentrional: comparação e descrição. Manaus: EDUA,

\footnotetext{
${ }^{16}$ Note that this implies that $W$ realis marker $-n(\dot{t})$ and $W$ possession marker $-n(\dot{t})$, which several analysts see as the same element, were actually two distinct suffixes in Proto-Pidjanan.
} 
2001.

SANTOS, M. G. Uma gramática do Wapishana (Aruák): aspectos da fonologia, da morfologia e da sintaxe. 2006. Tese (Doutorado), Instituto de Estudos da Linguagem, Universidade Estadual de Campinas, Campinas, 2006.

SB (SURINAAMS BIJBELGENOOTSCHAP / SURINAME BIBLE SOCIETY). Kaimana'o Tominkaru Paradan (The New Testament). Paramaribo, Georgetown: Suriname Bible Society and Guyana Bible Society, 2012.

SILVA, B.; SILVA, N. DE S.; OLIVEIRA, O. Paradakary Urudnaa. Dicionário Wapichana/Português Português/Wapichana. Boa Vista: EdUFRR, 2013.

SWADESH, M. The origin and diversification of language. Edition post-mortem by Joel Sherzer. Chicago: Aldine, 1971.

TRACY, F. V. Wapishana Phonology. In I. Davis (ed.). Languages of the Guianas. Summer Institute of Linguistics Publications in Linguistics and Related Fields, n. 35. Norman: Summer Institute of Linguistics and University of Oklahoma (USA), 1972. p. 78-84.

TRACY, F. V. An introduction to Wapishana verb morphology. International Journal of American Linguistics, vol. 40, n. 2, p. 120-125, 1974.

WALKER, R. S.; RIBEIRO, L. A. Bayesian phylogeography of the Arawak expansion in lowland South America. Proceedings of the Royal Society B: Biological Sciences, Vol. 278, n. 1718, p. 2562-2567, 2011 (doi: 10.1098/rspb.2010.2579).

WLP (WAPISHANA LANGUAGE PROJECT). Tominpainao Ati'o Wapichan Paradan Paradakaru na'iki Paradauzo-karu kaduzu. Scholar's Dictionary and Grammar of the Wapishana Language. Lethem: Wapishana Language Project, Rupununi, Region 9, Guyana. Porto Velho: SIL International, 2000.

WLP (WAPISHANA LANGUAGE PROJECT). Wapishana Primer. Lethem: Wapishana Language Project, Rupununi, Region 9, Guyana. Porto Velho: SIL International, 2001 (1986). 


\section{APPENDIX}

This is a list of all Wapishana-Mawana cognates found in the available data. The cog- nate sets are alphabetized by (English) meaning. Each set includes the meaning (with a parenthetic 'to' if the meaning is verbal: e.g., GIVE (TO)), the reconstructed protoform (with a question mark when it is problematic), the cognates ( $M=$ Mawayana, $W=$ Wapishana; variants are separated by commas), and comments. The meaning of a cognate is given only if it differs from the meaning of the set. If cognates include affixes, these are segmented out with hyphens; the target of cognacy, written in bold, is usually the stem. The most frequent affixes are listed in Table 17 below.

Table 17: Frequent affixes in Pidjanan languages. (Person prefixes mark posessors on nouns, argu- ments on postpositions, and subjects on transitive and active (in Wapishana, all) intransitive verbs; person suffxes mark objects on transitive verbs and, in Mawayana, subjects on stative intransitive verbs. If a suffix does not exist, the corresponding free pronoun is used)

\begin{tabular}{|c|c|c|c|c|c|c|}
\hline \multicolumn{3}{|c|}{ MAWAYANA } & \multicolumn{4}{|c|}{ WAPISHANA } \\
\hline person affixes: & \multicolumn{2}{|c|}{ verbal affixes: } & \multicolumn{2}{|c|}{ person affixes: } & \multicolumn{2}{|c|}{ verbal affixes: } \\
\hline $1 \mathrm{sg} . \quad \mathrm{n}-/ \mathrm{m}--\mathrm{na}$ & thematic & -ta, -da, -ba & 1. sg. & $\tilde{u}-\quad-n$ & thematic & $-p a,-t a,-k a$ \\
\hline 2. sg. $\dot{i}-/ i-\quad-i$ & present & $-e$ & 2. sg. & 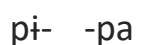 & realis & $-n$ \\
\hline 3. sg. $\quad r(\dot{t} / \mathrm{i}\})--s \dot{t}$ & reciprocal & -(a)ka & 3. masc. & $\dot{t}-\quad-z \dot{t}$ & desire & -azu(:) \\
\hline 3 refl. a- & adjectival & -re, -ke & 3 fem. & $u-\quad-z u$ & perfectve & -Paka \\
\hline 1 pl. wa- & & & 3 refl. & pa- & reflexive & - in $\sim-\pi:$ \\
\hline 2. pl. $\dot{+}-$ & & & $1 \mathrm{pl}$. & wa- & reciprocal & -a:ka \\
\hline 3. pl. na- & & & $2 \mathrm{pl}$. & $\dot{\mathrm{t}}-$ & passive & $-k a u$ \\
\hline & & & 3 pl. & ĩ- & nomnlzr. & $-? u$ \\
\hline
\end{tabular}

The default source for the data is the author's fieldwork. If there are disagreements between sources, or if a specific form is attested only in a source other than the author's fieldwork, then the source will be identified by a number: for Mawayana, M1 = Howard 1985-1986, M2 = Carlin 2006, M3 = Carlin (no date); and, for Wapishana, W1 = WLP 2000, W2 = Silva, Silva \& Oliveira 2013, W3 = WLP 2001, W4 = Melville, Tracy \& Williams 2007, and W5 = SB 2012.

1

\begin{tabular}{lll}
\multicolumn{2}{c}{ AÇAÍ PALM } & $*$ wabu \\
$\mathrm{M}$ & wabu & \\
$\mathrm{W}_{1}$ & wabu
\end{tabular}

Plausible borrowing from Cariban (cf. Waiwai wa:фu 'açaí berry').

\begin{tabular}{lll}
\hline 2 & & \\
ACOUCHY & *aduri \\
M & aduri & \\
W $_{1}$ & aduri & \\
\hline 3 & & \\
ANT SP. & *kuki \\
M & kuki & 'saúva' \\
W & kuki & 'leaf cutter ant'
\end{tabular}

4 ARMADILLO SP. $\quad *$ mVrurV ? M murura 'armadillo sp.' W maruru 'giant armadillo A Wanderwort (see Haynie et al. 2014), widespread in Amazonia (e.g., morura, in the neighboring Cariban language Waiwai), with irregular a : u and $u$ : a correspondences that may result from different loan sources (in which case it is not reconstructible to Proto-Pidjanan), or post facto modifi-cations due to contact with other lan-guages (in which case it may be re-constructible as a loan into Proto-Pidjanan). Note that the Mawayana, now living with the Waiwai, have a term closer to its Waiwai equivalent.
5

$\begin{array}{ll}\text { ARMPIT } & * \text { kisapu } \\ \text { M } & \text { ri-ke:su } \\ \text { W } & \text { i-kijapu }\end{array}$

Regular development: *kisapu > *kisaßu > *kisau > ke:su (the last step with compensatory lengthening).

\begin{tabular}{lcc}
\hline 6 & & \\
AS (ESSIVE) & $*$ ni: \\
$M_{2} \quad$ ni & '(change) into' \\
W & ni: & 'future', 'essive' \\
\hline 7 & & \\
BACABA PALM & *mapiri \\
M & misi & \\
$W_{1}$ & mapiża &
\end{tabular}


PP *mapiri $>*_{\text {mapisi }}^{*}>*_{\text {mais }}>\mathrm{M}$ mist. $W_{1}$ mapiza is listed as unidentified, but $W_{2}$ mapiz is glossed as 'Bacaba'. $W_{1}$ final a does not agree with $M$ final $\dot{i}$, probably because of confusion due to the ongoing loss of unstressed vowels. $\mathrm{M}+$ must be the etymologically correct vowel.

\begin{tabular}{|c|c|c|}
\hline 8 & & \\
\hline BAN & & *sit:rit \\
\hline$M$ & sisiba & \\
\hline$W_{1}$ & si:zit & \\
\hline 9 & & \\
\hline BAT & & *tamariwa \\
\hline$M$ & tamariwa & \\
\hline$W_{1}$ & tamariu & \\
\hline 10 & & \\
\hline BAT & (TO) & *kawa \\
\hline$M_{3}$ & kaw-e & \\
\hline$W_{2}$ & ũ-kau-pa-n & \\
\hline
\end{tabular}

$M$ stem-final a becomes e in verbs in the present tense. Therefore, $M_{3} \mathrm{e}$ implies a stem-final a.

\begin{tabular}{lll}
\hline 11 & & *kasuru: \\
BEADS & & \\
$M$ & kasuru & \\
$\mathrm{W}_{1}$ & kafuru: & \\
\hline 12 & & \\
BEE/HONEY & *ma:ba \\
M & maba & \\
W & ma:ba & \\
\hline 13 & & \\
BELT & & *rantawi \\
$M$ & i-rantawida & \\
$W_{1}$ & za:dawi &
\end{tabular}

The final $i: i$ correspondence is irregular. $\mathrm{W}$ i may result from confusion caused by ongoing unstressed vowel loss; $\mathrm{M} \dot{\dagger}$ is thus reconstructed. Also, the $n: \varnothing$ correspondence is actually the only instance of a $\mathrm{M}$ nasal-stop cluster in the available comparative data. Apparently, such clusters survived in Mawayana, but changed into d with compensatory lengthening in Wapishana.
14

BIRD

*kutipira

$\begin{array}{ll}\text { M } & \text { kutfisa } \\ \text { W } & \text { kutipiza }\end{array}$

$\begin{array}{ll} & \\ 15 & \text { *anarau }\end{array}$

M anaru 'socó (heron sp.)'

$W_{2}$ anarau 'marrecão (duck sp.)'

16

BIRD SP. 2 *ma(r)ati

M ma:ti 'jacu bird'

$W_{1}$ marati 'unidentified bird'

Possible borrowing from Cariban (cf. Waiwai marati 'jacu', Penelope sp., a species of guan). The $r: \varnothing$ correspondence is irregular (cf. $r: r$ in LANGUAGE, with the same environment) and is tentatively reconstruct-ed as $*(r)$; note that Waiwai marati supports an ${ }^{*} r$ here. Alternatively, it may stem from independent cases of borrowing from different source languages.

\begin{tabular}{lll}
\hline 17 & & \\
BIRD SP. 3 & *karapa \\
M3 & karahpada & 'arahka' \\
$W_{3}$ & karapa & 'Aracuã'
\end{tabular}

$\mathrm{M}_{3}$ identification 'arahka' is from Tiriyó (Cariban) arahka, identified as Ortalis ruficauda (Cracidae); $W_{3}$ (Port.) aracuã is also Ortalis spp. $\mathrm{M}_{3}$ $h p$ is probably just $p$ (it is the only attested example of a $\mathrm{M}$ h-cluster, $\mathrm{M}$ $\mathrm{h}$ being, in addition, rare and probably non-phonemic. Alternatively, hp might represent $[\phi]$, as it does in Tiriyó spelling (note that $M_{3}$, a Mawa-yana text, also has a Tiriyó version, showing that its author was familiar with Tiriyó orthography). This suggests that $\mathrm{M}_{3}$ karahpada may be (partially) borrowed from Tiriyó, or have undergone Tiriyó influence.

\begin{tabular}{|c|c|c|}
\hline \\
\hline \multicolumn{2}{|c|}{$\begin{array}{l}18 \\
\text { BITE (TO) }\end{array}$} & *a(r)u:ta \\
\hline $\mathrm{M}_{2}$ & r-autfa-na & 'he bit me' \\
\hline$W_{2}$ & aru:ta-n & \\
\hline
\end{tabular}

The $r$ : $\varnothing$ correspondence is irregular (cf. $r$ : r in PARROT SP. , MOTHER, etc., with the same environment) and is tentatively reconstructed as $*(r)$.

\begin{tabular}{|c|c|c|}
\hline \multicolumn{3}{|l|}{19} \\
\hline BLACK & & *pudi \\
\hline$M$ & udi-re & \\
\hline W1 & pudi-?u & \\
\hline
\end{tabular}

In $\mathrm{M}_{1}$, both udi-re and wudi-re are attested, which, if true, provides additional evidence for initial consonant loss (PP * $\left.p>*^{*}>*^{*}>\varnothing\right)$.

\begin{tabular}{lll}
\hline 20 & & \\
BLOW (TO) & *pu:ta \\
$M_{1}$ & r-utf-e & \\
$W_{1}$ & i-pu:ta-n
\end{tabular}

$M$ stem-final a becomes e in verbs in the present tense. Therefore, $\mathrm{M}_{1} \mathrm{e}$ implies a stem-final a (utfa).

\begin{tabular}{lll}
\hline 21 & & \\
BRAZIL NUT & $*$ minai \\
M & mini & 'peanut', 'Brazil nut' \\
$W_{1}$ & minai & \\
\hline 22 & & \\
BREAST & $*$ dinj \\
M & ri:-di & \\
$W_{1}$ & i-dini &
\end{tabular}

$W_{1}$ dini 'breast' also means 'milk'. Note n-loss without nasalization.

\begin{tabular}{|c|c|c|}
\hline \multicolumn{3}{|l|}{23} \\
\hline \multicolumn{2}{|c|}{ BURITI PALM } & $* d^{j} \mathbf{i} w \mathbf{i}$ \\
\hline$M$ & jïwi & 'buriti' \\
\hline$W_{1}$ & djiwi $^{\mathbf{i}}$ & 'Ité fruit' \\
\hline \multicolumn{3}{|l|}{$\overline{24}$} \\
\hline \multicolumn{2}{|c|}{ BURN (TO) } & *kaPawa \\
\hline$M$ & kaw-e & 'burn (intr.)' \\
\hline$W_{1}$ & kaPawa-n & 'burn (intr.)' \\
\hline
\end{tabular}

$M$ stem-final a becomes e in verbs in the present tense. Therefore, $\mathrm{M}_{3} \mathrm{e}$ implies a stem-final a (kawa).

\begin{tabular}{lll}
\hline 25 & & \\
BUTTERFLY & *tsamatsama \\
M & samasama & \\
$\mathrm{W}_{1}$ & tamtam &
\end{tabular}


Possible borrowing from Cariban (cf. Waiwai tamatama 'butterfly'), maybe also sound-symbolic and reduplicated.

\begin{tabular}{|c|c|c|}
\hline \multicolumn{3}{|l|}{26} \\
\hline \multicolumn{2}{|c|}{ CAIMAN SP. } & *aturi \\
\hline$M$ & atfuri & \\
\hline W & aturi & 'small caiman' \\
\hline \multicolumn{3}{|l|}{27} \\
\hline \multicolumn{2}{|c|}{ CAJÁ FRUIT } & *ru:ba \\
\hline$M$ & ruba & \\
\hline$W_{2}$ & zu:p & \\
\hline
\end{tabular}

$W_{2}$ often misses final vowels, due to ongoing unstressed vowel loss; $\mathrm{M}$ a is thus reconstructed. It also sometimes mistranscribes final $b$ as $p$. It is thus quite likely that zu:p is really zu:ba, in which case irregular $b: p$ really is the regular $b: b$ correspondence, immediately reconstructible as $\mathrm{PP} * \mathrm{~b}$.

\begin{tabular}{lll}
\hline 28 & & \\
CANOE & *kanawa \\
$M$ & kanawa & \\
$\mathrm{W}_{1}$ & kanawa &
\end{tabular}

Possible borrowing from Cariban (cf. Waiwai, Tiriyó kanawa 'canoe').

\begin{tabular}{lll}
\hline 29 & & \\
CAPYBARA & $*$ kasu \\
M & kasu & \\
W $_{1}$ & kafu & \\
\hline 30 & & \\
CHILD & & *kurai- \\
M & kurenu & \\
W & kuraidauna: &
\end{tabular}

The final elements are clearly not cognate. M nu may be from the plural ending *-nawi, sometimes found in singular words (see OLD MAN). W final dauna: is perhaps comparable to W daunai(?)ura 'man', 'male'.

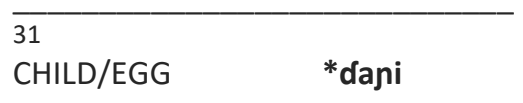

PP *dani $>*$ dai $>$ M de, without nasalization and with diphthong reduction. $M$ final si is probably a masculine ending (cf. W -zit and $M$-si on transitive verbs; cf. also feminine ru in $\mathrm{M}$ ri:-deru 'his daughter').

\begin{tabular}{lll}
\hline 32 & & \\
CICADA & $*$ wamu \\
$M$ & womu & \\
$\mathrm{W}_{2}$ & wamu &
\end{tabular}

Note the assimilation in Mawayana (PP * wamu > M womu). $\mathrm{M}$ o is currently analyzed as an allophone of $u$, i.e., $\mathrm{M}$ womu = /wumu/.

\begin{tabular}{lcl}
\hline 33 & & \\
CLAW/NAIL & *bad $\mathbf{j i}$ \\
$M$ & ri-badji & \\
$W_{1}$ & i-bazi & \\
\hline 34 & & \\
COATI & & *kuadji \\
M & kadi & \\
$W_{1}$ & kuatji & \\
&
\end{tabular}

Obviously a Tupian loan: cf. Proto Tupi-Guarani *kwati (in Mello 2000: 320). $W_{1}$ has kuwatfi, but since its evolution differs from that of MONKEY SP. 3 * puwati $(*$ ua $>$ a diphthong reduction instead of *wa $>$ wo assimilation in Mawayana), and given its Tupian source, it is probably kuatfi.

\begin{tabular}{lll}
\hline 35 & & \\
COCKROACH & $*$ basarawa \\
$\mathrm{M}$ & basarawa & \\
$\mathrm{W}_{1}$ & bafarau & \\
\hline 36 & & \\
$\mathrm{COMB}$ & & $*$ mauCi \\
$\mathrm{M}$ & mutiba & \\
$\mathrm{W}_{1}$ & maudi & \\
&
\end{tabular}

The irregular $\mathrm{t}: \mathrm{d}$ correspondence is here reconstructed as an undetermined consonant ${ }^{*} \mathrm{C}$ Note also diphthong reduction in Mawayana.

\begin{tabular}{|c|c|c|}
\hline \multicolumn{3}{|l|}{37} \\
\hline CORN & & ${ }^{*}$ mariki \\
\hline M & mariki & \\
\hline$W_{1}$ & maziki & \\
\hline
\end{tabular}

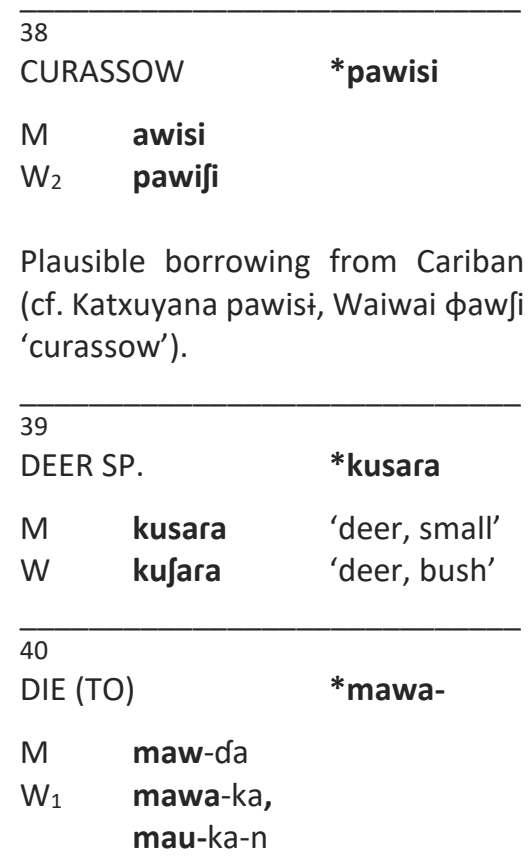

W final a sometimes disappears because of ongoing unstressed vowel loss.

\begin{tabular}{|c|c|c|}
\hline 41 & & \\
\hline DRY & & *ma:ra \\
\hline $\mathrm{M}_{1}$ & mara-ba-si & \\
\hline$W_{1}$ & ma:ra-n & \\
\hline 42 & & \\
\hline EAC & SP. & *kuku- \\
\hline$M$ & kukuda & 'hawk sp.' \\
\hline$W_{1}$ & kukui & 'harpy eagle' \\
\hline 43 & & \\
\hline EAR & WORM & *pararu \\
\hline$M$ & araru & \\
\hline$W_{1}$ & pazaru & \\
\hline 44 & & \\
\hline EAT & & *nika \\
\hline$M$ & r-îka & \\
\hline$W_{1}$ & pi-nika & \\
\hline 45 & & \\
\hline ELB & & *paturi \\
\hline M & ri:-фatfuri & \\
\hline$W_{1}$ & i-paturi & \\
\hline
\end{tabular}

This is the only example of a $\phi: p$ correspondence; in fact, it is the only example of $\mathrm{M} \phi$ in the available data. It is probably the result of Waiwai in-fluence (Waiwai has 
phonemic $/ \phi /$, including in aфoresi 'elbow'). W $\mathrm{p}$ is thus reconstructed.

\begin{tabular}{lc}
\hline 46 & \\
ELECTRIC EEL & *katsumi \\
M & katumi \\
W $_{1}$ & kasumi \\
\hline 47 & \\
FAN & *awariba \\
M & wiribe, n-wiriba \\
$W_{1}$ & awariba-i
\end{tabular}

Note M final e (NON-POSSESSED) / a (POSSESSED) alternation, corresponding to $\mathrm{W}-\mathrm{i}$ 'NON-POSSESSED'. This is probably an instrument nomi-nalization (cf. W nominalizer riba, non-possessed form -riba-i, and $\mathrm{W}$ awaria-n to fan, gesture, beck-on'; see also WIND). The i : a corres-pondence is irregular, but *a $>$ i seems more plausible than $* a>i$, espe-cially if this word is a nominaliza-tion, with *riri > ri by haplology (*awari(a)-riba-i > *awariribai $>$ *awiriribai > *awiribai $>\mathrm{M}$ wiribe). Thus, ${ }^{*}$ a is tentatively reconstructed.

\section{8}

$\begin{array}{ll}\text { FATHER } & * \text { Ca } \\ \text { M } & \text { ri-ta } \\ \text { W } & \text { i-dari }\end{array}$

The $W$ final it is a reflex of the old masculine suffix -rit (see MOTHER for its feminine counterpart -ru). It is not clear whether or not it should be reconstructed to PP. The irregular $\mathrm{t}$ : $\mathrm{d}$ correspondence is reconstructed as an undetermined consonant ${ }^{*} \mathrm{C}$.

\begin{tabular}{lll}
\hline 49 & & *tikari \\
FIRE & & \\
M & fikari & \\
W & tikazi & \\
\hline 50 & & \\
FISH & & \\
M & kuwi \\
W & kupai & \\
PP *kupai $>$ *kußai > M kuwi.
\end{tabular}

51

\begin{tabular}{lll}
\multicolumn{2}{l}{ FISH SP. 1} & *ri.ta \\
M & ritfe & 'traíra' \\
W $_{1}$ & zi:taba & 'fish sp.' \\
\hline 52 & & *atfimara \\
FISH SP. 2 & 'trairão' \\
M & atimara & 'fish sp.' \\
$W_{1}$ & atfimara & \\
\hline 53 & & \\
FISH SP. 3 & *kuriti \\
M & kurisi & 'surubim' \\
$W_{1}$ & kurizi & 'surubim'
\end{tabular}

$W_{1}$ kurizit occurred in a list of unidentified fish; in $W_{2}$, kuriz (without the final vowel) occurred, identified as 'Surubim'.

\begin{tabular}{lll}
\hline 54 & & \\
FLAT AREA & *da:ra \\
$M$ & dara & 'grass(land)' \\
$\mathrm{W}_{1} \quad$ da:ra & 'a flat barrier' \\
\hline 55 & & \\
FLOWER & *siwi \\
$\mathrm{M}_{1}$ & ri-siwi & \\
$\mathrm{W}_{1}$ & i-su:su &
\end{tabular}

W final su is probably reduplicat-ed (*siwi-siwi > * siwsiw > W su:su), which explains the irregular $\dot{i}: \mathrm{u}$ correspondence.

\begin{tabular}{lll}
\hline 56 & & $*(r)$ iki \\
FROM & & 'from there' \\
$M_{2}$ & a?u-riki & \\
$W_{1}$ & iki &
\end{tabular}

$M_{2}$ initial r occurs at the boundary of a locative morpheme with poorly understood history. Thus, it is only tentatively reconstructed as * $(r)$.

\begin{tabular}{lll}
\hline 57 & & \\
FRUIT & & $*(a) k a$ \\
$M$ & ri-ka & \\
$W_{1}$ & i-aka &
\end{tabular}

The lack of $M$ initial a is rather surprising and remains unexplained. It is only tentatively reconstructed.
58

GIVE (TO) *ta:

$\begin{array}{ll}M_{1} & \text { ri-tf-e-si } \\ W & \text { i-ta:-n }\end{array}$

$M$ stem-final a becomes e in verbs in the present tense. Therefore, $\mathrm{M}_{3} \mathrm{e}$ implies a stem-final a ( $\mathrm{t} a$ ).

\begin{tabular}{|c|c|c|}
\hline \multicolumn{3}{|l|}{59} \\
\hline \multicolumn{2}{|c|}{ GRANDMOTHER } & $*(\delta) \mathrm{V}: \mathrm{ru}$ ? \\
\hline$M$ & wa-Juru & \\
\hline$W_{1}$ & ip- i:zu & \\
\hline
\end{tabular}

Two irregular correspondences, $\mathrm{u}: \dot{\dagger}$ and $\int: \varnothing$ (the latter only occurs in this set) make this reconstruction problematic: the two terms may not be cognate. To mark this uncertainty, $\int: \varnothing$ is reconstructed as a parenthetical $*(\delta)$, and $u: \dot{i}$ as an undermined vowel *V.

\begin{tabular}{lll}
\hline 60 & & \\
HAIR & & $*_{\text {iCi }}$ \\
M & r-ijirama & \\
W $_{1}$ & i-iji
\end{tabular}

This is the only set with a $\int: \int$ correspondence; note the contrast with $\mathrm{s}$ : $\int\left(<\mathrm{PP}{ }^{*} \mathrm{~s}\right)$ in, e.g., CURASSOW, and with $\int: t$ in, e.g., FIRE. It is difficult to determine which consonant is to be reconstructed here, hence the undetermined ${ }^{*} \mathrm{C}$.

\begin{tabular}{lll}
\hline 61 & & $*$ \\
HAND & & *kapi \\
M & ri-kiba & \\
W & i-kaP; &
\end{tabular}

From PP *kapi > *kaj > M ki + an extra element ba.

\begin{tabular}{|c|c|c|}
\hline \multicolumn{3}{|l|}{62} \\
\hline HEART & & $*_{\text {nikinija }}$ \\
\hline$M$ & ri:P-ĩkĩjã & \\
\hline$W_{1}$ & i-nikini: & \\
\hline
\end{tabular}

The irregular $\tilde{\imath}: \gtreqless$ correspondence seems to result from $\mathrm{n}$-loss and irregular (cf. BREAST) i-to-i palatalization (*nikinija > *ĩkinija > M ĩkĩja [ĩkĩnã]). W nikini: irregularly conserves the initial *n, perhaps because the initial syllable may be an 
independent element having its own history. Payne (1991, p. 407) shows cognates with apparently non-cognate initial elements: e.g., Machiguenga nigakji- (note the extra g), Palikur h-açi. In addition, $\mathrm{n}$ is a rare phoneme in Wa-pishana: its only occurrences in the available data are nikini: 'heart, feelings', the clearly related verb nikinia, nikini:pa 'remember' with its opposite manikinia 'forget', and the possibly related noun wanikini: 'food'.

\begin{tabular}{|c|c|}
\hline \multicolumn{2}{|l|}{63} \\
\hline HIT (TO) & *ruPita \\
\hline$M_{1}$ rita-ka-nu & 'hit each other' \\
\hline$W_{1}$ i-zuPita-n & 'he hit' \\
\hline
\end{tabular}

PP * ruPita $>*$ ruita $>M$ rita. Note the $\mathrm{t}$ : $\mathrm{t}$ correspondence, which should not occur word-medially; in this case, however, the final -ta is probably an independent affix (one of the Arawakan verbal 'thematic syllables,' old derivational affixes often no longer segmentable) that may have its own history.

\begin{tabular}{llr}
\hline 64 & \\
HOUSE & *pani- \\
$M$ & aĩku & \\
W $_{1}$ paniba & 'outside' \\
& pani:num & 'entrance, door, \\
& doorway'
\end{tabular}

W 'house' is kabain (non-possessed) or dapi (possessed); paniba and pani:num seem to contain an older stem pani-for this meaning. Cf. also фanitji 'house', from closely related Bahuana (RAMÍREZ, 1992, p. 111). $\mathrm{M}$ aĩ- is to be expected, given $\mathrm{p}$ - and n-loss (*pani- > *ani- > M aĩ-) with nasalization and no diphthong reduction.

\begin{tabular}{l}
\hline 65 \\
I \\
M nnu \\
$W_{1} \quad$ ũgari \\
W final element ( + )gart (so far \\
unidentified) is found only in some \\
pro-nouns: pigarł 'you sg.', paigarł \\
's/he' (same as subject). Its absence
\end{tabular}

in Ma-wayana implies that at least some Proto-Pidjanan personmarking pre-fixes or clitics (*nnu, maybe also *pi 'you', etc.) could also function as in-dependent pronouns.

$M$ initial nn may be a Proto-Pidja-nan feature, or it may result from a language-internal constraint on the shape of monosyllables. Since M nnu apparently contrasts with $\mathrm{M}$ nu 'ant sp.', initial nn must not be an automatic feature of monosyllables and is thus reconstructed.

$\overline{66}$
IF/WHEN
$\mathrm{M}_{2}$ ana
$\mathrm{W}_{1}$ ana

$M_{2}$ a-na is segmentable, -na being the first-person marker ('when I'), which suggests that all person markers can occur in this word (and that this was also true in Proto-Pidjanan). In Wapishana, ana ( $W_{3}$ an) has become a simple word, with no synchronic person markers.

\begin{tabular}{|c|c|c|}
\hline \multicolumn{3}{|l|}{67} \\
\hline IGUANA & & *suwana \\
\hline$M$ & suwanada & \\
\hline$W_{1}$ & suwan & \\
\hline
\end{tabular}

W final vowel was not transcribed; given the $M$ form, it is probably a. Note that this is a geographically very widespread word (a Wanderwort; see Haynie et al., 2014) and is a probable loanword, apparently already in Proto-Pidjanan or maybe even earlier.

\begin{tabular}{lll}
\hline 68 & & \\
INAJÁ PALM & *puk-? \\
M & ukati & 'inajá' \\
$W_{1}$ & pukuridi & 'kokorite palm'
\end{tabular}

Only the initial parts (M uk-, $W_{1}$ puk-) seem to be cognate. Closely related Bahuana ukarici 'inajá' (RAMíREZ, 1992, p. 117) makes cognacy somewhat more plausible. Still, only the ini-tial element is tentatively reconstructed.

\begin{tabular}{|c|c|c|}
\hline \multicolumn{2}{|c|}{ INGÁ TREE } & \multirow{2}{*}{$\begin{array}{l}\text { *kurami } \\
\text { 'ingá' }\end{array}$} \\
\hline $\mathrm{M}$ & kurami & \\
\hline$W_{2}$ & kurami & 'ingá do mato' \\
\hline \multicolumn{3}{|l|}{70} \\
\hline \multicolumn{2}{|c|}{ INTESTINES } & *ukuri(ri) \\
\hline$M$ & r-ukuriri & \\
\hline W & i-ukuri & \\
\hline
\end{tabular}

It is unclear whether or not the second $\mathrm{M}$ ri should be reconstructed.

\begin{tabular}{|c|c|c|}
\hline \multicolumn{3}{|l|}{71} \\
\hline KNEE & & *kuduru \\
\hline$M$ & ri:-kuduru & \\
\hline W & i-kuduru & \\
\hline \multicolumn{3}{|l|}{$\overline{72}$} \\
\hline KNIFE & & *marija \\
\hline$M$ & mare & \\
\hline W & mari:, i-ma & $a-n$ \\
\hline
\end{tabular}

Possible borrowing from Cariban (cf. Waiwai marija 'knife'). The final syllable ja is reconstructed, since it is present in the $\mathrm{W}$ possessed form and explains final length in the nonpossessed form (PP *marija> *marija > W mari:) and $M$ final e instead of $i$, via a-to-e raising and diphthong reduction (PP *marija > ${ }^{*}$ mari(j)e $>*_{\text {marie }}>$ M mare).

\begin{tabular}{lll}
\hline 73 & & \\
\multicolumn{2}{l}{ LANGUAGE } & *para \\
M & ri:P-ara & \\
$W_{1}$ & i-parada-n & \\
\hline 74 & & *anaba \\
LEAF & & \\
M & r-anaba & \\
$W_{1}$ & i-anaba & \\
\hline 75 & & \\
LEFT-HAND & *asVba-
\end{tabular}

\section{$\mathrm{M}_{1}$ asubadianu 'right hand' \\ $\mathrm{W}_{2}$ ajabaru}

The $\mathrm{W}$ meaning is independently attested in different sources $\left(W_{1}, W_{2}\right.$, $\left.W_{4}\right)$. The $M$ meaning is attested only once in a word list with good chance of mistranslation; it is assumed to be wrong. The $u:$ a correspondence is 
irregular and thus only warrants the reconstruction of an undetermined vowel *V. The final elements ru and djanu remain unidentified.

\begin{tabular}{|c|c|c|}
\hline \multicolumn{3}{|l|}{76} \\
\hline LEC & & *(i)taba \\
\hline$M$ & ri:-faba & 'leg, shin' \\
\hline W & i-taba?u & 'leg' \\
\hline
\end{tabular}

Cf. also $W_{1}$ taba?una:, taba?unau 'shin', clearly derived from taba?u.

\begin{tabular}{lll}
\hline 77 & & \\
LOUSE & & *nnai \\
M & nni & \\
W & nai &
\end{tabular}

See I (pronoun) for the reason to reconstruct PP initial *nn instead of attributing $M \mathrm{nn}$ to idiosyncratic compensatory lengthening.

\begin{tabular}{llc}
\hline 78 & & \\
MACAW SP. & $*(k)$ araru \\
M & araru & 'yellow macaw' \\
$W_{1}$ & kazari & 'yellow macaw'
\end{tabular}

$W_{1}$ initial $k$ may be a separate element, perhaps created by analogy with non-Arawakan words; cf. neighboring Cariban languages Waiwai (kwajari), Tiriyó (kujari), both 'red macaw sp.'. The final $u$ : $\dot{+}$ correspondence is irregular. $\mathrm{W}+$ may be the result of confusion due to ongoing unstressed vowel loss; therefore, $\mathrm{M} u$ is reconstructed instead.

\begin{tabular}{lll}
\hline 79 & & \\
MANIOC & *kanirit \\
M & ka:sí, kã:si & \\
W $_{1}$ & kaniżi
\end{tabular}

It is unclear, based on the available data, whether or not M ka:si kã:si is nasal. Diphthong reduction after $\mathrm{n}$ loss would lead to *kist or *kĩst, and a simple block of this change would yield *katssi. One possibility is the effect of an intermediate nasal coda:

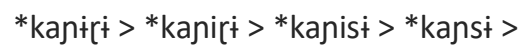
ka:sł, kã:sł (cf. SWEET POTATO for a possible case of $*_{\dot{i}}$ loss).
80

$\begin{array}{ll}\text { MANIOC PRESS } & *(\mathrm{n}) \mathrm{i} \text { ru- ? } \\ \mathrm{M} & \text { isune } \\ \mathrm{W}_{1} & \text { ni:zu }\end{array}$

This set is at best partially cognate ( ${ }^{*}$-i:su-), and may even not be cognate at all. The reconstruction of the common element is tentative.

\begin{tabular}{ll}
\hline 81 & \\
MEAT FOOD & $*$ wini \\
$M_{1}$ & wĩ, ri-wini \\
$W_{1}$ & wini-i, i-wini
\end{tabular}

From PP non-possessed *wini-i, one derives * wini > *wĩi > M wĩ. The possessed form, however, has a final syllable -ni. We propose that this final syllable either is, or was reshaped by analogy with, the possession marker -ni (e.g., M ri-mare-ni 'his

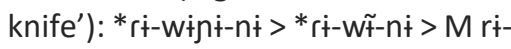
wint. This led to the $M$ irregular possession paradigm wĩ / wint.

\begin{tabular}{lll}
\hline 82 & & \\
MEDICINE & $*$-tsara \\
$M$ & ri-itara & \\
$W_{1}$ & i-kasara
\end{tabular}

Initial W ka might be the 'having' verbalizer ka-, in which case the basic nominal stem would be sara, closer to M itara.

\begin{tabular}{ll}
\hline 83 & \\
MONKEY SP. 1 & *ru:mu \\
M rumu & 'spider monkey' \\
W ru:mi & 'spider monkey'
\end{tabular}

The final $\mathrm{u}$ : i correspondence is irregular. W i may result from confusion caused by ongoing unstressed vowel loss; therefore, $\mathrm{M} \mathrm{u}$ is reconstructed instead.

\begin{tabular}{lcc}
\hline 84 & & \\
MONKEY SP. 2 & *tsibiri \\
M & tibirit & 'howler monkey' \\
W & sibiri & 'howler monkey' \\
& & \\
\hline 85 & & \\
MONKEY SP. 3 & *puwati
\end{tabular}

M otfi 'capuchin monkey' W puwati 'capuchin monkey'

Note the $\mathrm{a}>\mathrm{o}$ assimilatory change in Mawayana (*puwati $>$ *puwot $>$

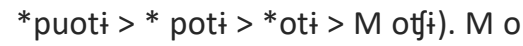
is analyzed as an allophone of $/ \mathrm{u} /$, i.e., $M$ otf $\dot{t}=/ u t f+$.

\begin{tabular}{|c|c|}
\hline 86 & \\
\hline MONKEY SP. 4 & *(i)tfaima: \\
\hline tfima & 'tamarin monkey' \\
\hline$W_{2}$ traima: & 'black tamarin' \\
\hline
\end{tabular}

This is the only example of a $t: t$ correspondence in the available data. The obvious reconstruction $(* t)$ is doubtful, since PP $* t$ should yield $\mathrm{M} t$ (see, e.g., TOUCAN SP. or TOAD SP.). An initial *(i) is tentatively reconstructed to block a $*_{\mathrm{t}}>\mathrm{t}$ change, but note that PECCARY SP. 2 suggests that a preceding $*_{i}$ should not block this change. Alternatively, $M$ initial $t$ might result from the influence of neighboring Cariban language Waiwai, in which 'tamarin' is tfi:ma.

\begin{tabular}{lll}
\hline 87 & & \\
MOON & & *kairi \\
M & kisi & \\
W & kaizzi & \\
\hline 88 & & \\
MOSQUITO SP. & $*$ mitsu \\
M & mitu & \\
W & misu & \\
\hline 89 & & \\
MOTHER & $*$ *aru \\
M & ri:-taru & \\
W & i-daru &
\end{tabular}

The final ru must be a reflex of the old feminine suffix -ru (see FATHER, with its masculine counterpart -ri). The irregular $t: d$ correspondence is reconstructed as an undetermined consonant ${ }^{*} \mathrm{C}$.

\begin{tabular}{lll}
\hline 90 & & \\
MURUMURU & *biri \\
M & birit & 'murumuru palm' \\
W $_{1}$ & birit & 'palm (unidentified)'
\end{tabular}


A palm tree (Astrocaryum sp.). Its seeds are used for handicraft.

\begin{tabular}{lll}
\hline 91 & & $*(i) d i b a$ \\
NOSE & & \\
M & ri-tiba & \\
W & i-idiba
\end{tabular}

The $\varnothing$ : i correspondence for the initial $\mathrm{i}$ is irregular and not clearly motivated by its surroundings. An initial *(i) can be only tentatively reconstructed.

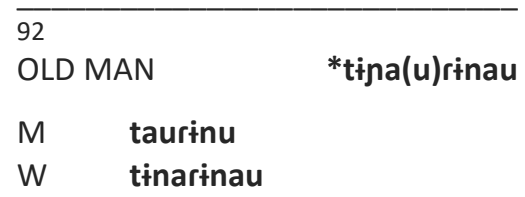

PP *tina(u)rinau $>*$ tia(u)rinau $>M$ taurinu (where the $*$ a, after becoming adjacent to the $*_{\mathrm{t}}$, apparently blocked PP *t > M t; see BAT for another example). The $u$ is in parenthesis because its existence is problematic: if it existed, it should have surived in Wapishana (but see OTHER for another such case). The ending nau is probably an old plural marker (<PP *-nawi). Note that it can remain unreduced in Mawayana (see SHAMAN).

\begin{tabular}{|c|c|c|}
\hline \multicolumn{3}{|l|}{93} \\
\hline \multicolumn{2}{|c|}{ OPOSSUM SP. } & *wa:tsa \\
\hline $\mathrm{M}$ & wata & 'opossum sp.' \\
\hline & wa:sa & 'opossum, wolly' \\
\hline \multicolumn{3}{|l|}{94} \\
\hline \multicolumn{2}{|c|}{ OTHER } & *baPurVnu \\
\hline $\begin{array}{l}\mathrm{M}_{1} \\
\mathrm{~W}_{1}\end{array}$ & $\begin{array}{l}\text { burunu } \\
\text { ba?ura }\end{array}$ & , ba?urani-aba \\
\hline
\end{tabular}

The $u$ : a correspondence in the 3rd syllable is irregular; an undetermined *V is thus reconstructed (but see OLD MAN for a possible *a(u) diphthong). The final $u$ : ‘ probably results from confusion in Wapishana due to ongoing unstressed vowel loss. $\mathrm{M}_{1}$ final $u$ is thus reconstructed.

95

PAPAYA

\section{M mabaja \\ $W_{1} \quad$ maPapai}

Possibly a borrowing (cf. English papaya, Tiriyó (Cariban) mapaja.) Before disappearing, the glottal stop may have changed PP *p into $M b$ ( ${ }^{*}$ ma جapaja > *maa?paja > mabaja).

\section{6 \\ M waru \\ $W_{1}$ waru}

PARROT SP. $\quad *$ waru

Plausible Cariban borrowing (cf. Waiwai kwaro, wa:ro 'parrot sp.').

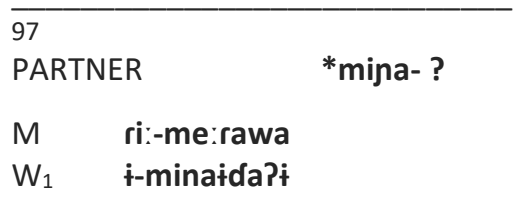

The words in this set are at best only partially cognate: PP *mina- $>{ }^{*}$ mia$>\mathrm{M}$ me:- (with diphthong reduction but no nasalization).

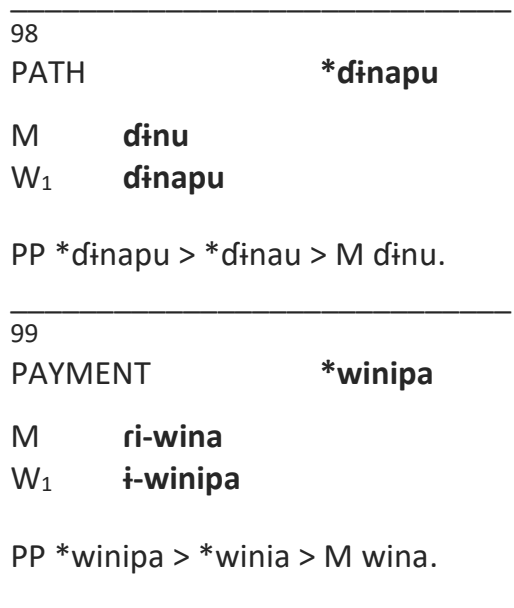

100

\section{PECCARY SP. 1 *bakira}

M bakira 'collared peccary'

W bakiri 'collared peccary'

Possible borrowing from Cariban (cf. Tiriyó, Wayana, Apalaí pakira 'collared peccary'), which suggests that the final vowel must have been *a, W i resulting from confusion due to ongoing unstressed vowel loss.
101

PECCARY SP. 2 *Citfa

M rita 'white-lipped peccary'

W bitfi, 'white-lipped peccary' bitfa

W bitya is assumed to be the older form and bitfi a newer variant, caused by confusion resulting from ongoing unstressed vowel loss.

The $r$ : $b$ correspondence is phonetically surprising. Outside of Pidjanan, its reflex is usually $p$ or $h$, suggesting a labial like ${ }^{*} b$ as the best reconstruction; still, $M r$ is unexplained, so that only an undetermined ${ }^{*} \mathrm{C}$ is reconstructed.

\begin{tabular}{ll}
\hline 102 & \\
PERSON & *pidana \\
M & die, die: $^{j}$ : \\
$W_{1} \quad$ pidan, pidana-n
\end{tabular}

PP *pidana > ${ }^{*}$ pid $^{j}$ a: $>*^{{ }_{i} d^{j} \mathrm{e}}$ : > M $\mathrm{d}^{\mathrm{j} e}(\mathrm{:})$, with $\mathrm{p}$-loss and *a-to-e raising because of the preceding $*_{i}$. Note final $\mathrm{n}$-loss without nasalization.

\begin{tabular}{|c|c|c|}
\hline \multicolumn{3}{|l|}{103} \\
\hline PET & & *ira \\
\hline $\mathrm{M}_{1}$ & r-isa & \\
\hline$W_{1}$ & †p-iza & \\
\hline \multicolumn{3}{|l|}{104} \\
\hline RED & & *wira \\
\hline M & usa-si & \\
\hline$W_{1}$ & wiz̨a-Pu & \\
\hline \multicolumn{3}{|l|}{105} \\
\hline RIB & & *aradi(di) \\
\hline M & \multirow{2}{*}{\multicolumn{2}{|c|}{$\begin{array}{l}\text { ri:?-aradi } \\
\text { i-aradidi, } \mathbf{i} \text {-aradiłi }\end{array}$}} \\
\hline W & & \\
\hline \multicolumn{3}{|l|}{106} \\
\hline ROPE & & *inu?i \\
\hline M & jũwi & \\
\hline$W_{1}$ & $\begin{array}{l}\text { inupi, } \\
\text { inubi }\end{array}$ & 'hammock rope' \\
\hline
\end{tabular}

The $W_{1}$ forms are apparently dialectal variants, of which inu?i is the easiest to connect to $M$ jũwi (*inu?i > *i.ũ ?i $>*$ jũ.i > jũwi), so $W_{1}$ inubi must be a more recent form. 
Note that, phonetically, $\mathrm{W}$ in $=$ [in] and $\mathrm{M}$ jũ $=$ [nũ].

\begin{tabular}{|c|c|c|}
\hline \multicolumn{3}{|l|}{107} \\
\hline SALT & & $*$ diwi \\
\hline M & diwi & \\
\hline$W_{1}$ & diwi & \\
\hline \multicolumn{3}{|l|}{108} \\
\hline SAND & & *ka:ti \\
\hline $\mathrm{M}_{1}$ & katfi & \\
\hline$W_{1}$ & ka:ti & \\
\hline \multicolumn{3}{|l|}{109} \\
\hline SEAT & & *(i)tsaba \\
\hline $\begin{array}{l}M \\
W_{1}\end{array}$ & $\begin{array}{l}\text { isabe, } \\
\text { taba-i }\end{array}$ & \\
\hline
\end{tabular}

$W_{1}$ final $-i$ is the suffix that marks nonpossessed forms, corresponding to the $M$ non-possessed form in $\mathrm{e}$ (*itaba-i $>M$ isabe).

110
SEE (TO) $\quad * t V k a$

$\begin{array}{ll}M & \text { ri-tfika } \\ \text { W } & \text { i- tika-pa-n }\end{array}$

The irregular i : $\dot{i}$ correspondence occurs here without any clear ProtoPidjanan palatalizing elements. One is tempted to reconstruct ${ }^{*} \dot{i}$, assuming that $\mathrm{M} t$ could change it to $i$, but there are obvious counterexamples (see, e.g., SAND, BIRD, MONKEY SP. 3, BIRD SP. 2). Therefore, an undetermined vowel $* \mathrm{~V}$ is reconstructed.

111

SHAMAN

*marinawi

M marinawi

The last syllables (nawi, nau) are probably a plural suffix $\left(<*^{*}\right.$-nawi). This suffix can sometimes be further reduced (see OLD MAN).

\begin{tabular}{lll}
\hline 112 & & \\
SHOULDER/ARM & *(i)tsawada \\
M & ri:-sawada & 'arm' \\
W & i- tawada & 'shoulder'
\end{tabular}

113

SIEVE

*manari

M manari

$W_{1}$ manari 'cassava sifter'

Possible borrowing, since this is a frequent word in Cariban languages, too (cf. Waiwai manari 'sieve').

\begin{tabular}{lll}
\hline 114 & & \\
SKIN/BARK & $*$ mada \\
M & ri:-mada & \\
$\mathrm{W}_{1}$ & i-mada & \\
\hline 115 & & \\
SKY & & $*$ Vkari \\
M & ikari & \\
W & aukazi &
\end{tabular}

The initial elements appear not to be cognate. It is unclear whether one of them, or neither, should be reconstructed. An undetermined element (vowel) *V is reconstructed to mark this uncertainty.

\begin{tabular}{llc}
\hline 116 & & \\
\multicolumn{2}{l}{ SLOTH SP. } & *awi \\
M & awi & \\
$W_{2} \quad$ awi & \\
\hline 117 & & \\
SMALL & *sudi ? \\
M1 & fidiidja-re & 'small, narrow' \\
W & sudi &
\end{tabular}

The $\int: s$ and $i$ : $u$ correspondences are surprising (SMALL is the only example for both): either the terms are not cognate, or they underwent idiosyncratic changes. Assuming the latter, the easiest path would be assimilation $\left({ }^{*} \mathrm{u}>\mathrm{i}\right)$ in Mawayana, followed by palatalization $\left({ }^{*} s,{ }^{*} d>\int, c^{j}\right)$.

\begin{tabular}{l}
\hline 118 \\
SMOKE \\
$\begin{array}{l}\text { M1 ise-si } \\
\text { ifa-n }\end{array}$ \\
Cf. also Wisa- $W_{1}$ ifa?uzi (variant ifa), \\
'clouds', tikazi Jan 'smoke' (< tikazi \\
'fire', fan 'cloud, haze'). Note that W \\
i is lost in some, but not all, forms.
\end{tabular}

119

SONG

*kini

M kini, ri:-kini

$W_{5} \quad k i n i-i, i-k i n i$

W final $-i$ is the suffix that marks non-possessed forms, corresponding to $M$ final i (PP * kini-i > M kini).

\begin{tabular}{|c|c|c|}
\hline 120 & & \\
\hline SPIDER & & $*(\mathrm{~s}) \mathrm{u}: \mathbf{w a}$ \\
\hline$M$ & uwaba & \\
\hline W & su:wa & \\
\hline
\end{tabular}

The final $s: \varnothing$ is an irregular correspondence: there is no other case that suggests initial s-loss in Mawayana (cf., e.g., IGUANA to see initial $s$ preserved). $W$ initial s may thus be a separate element and is only tentatively reconstructed as $*(s)$.

\begin{tabular}{lll}
\hline 121 & & *kiba \\
STONE & & \\
M & kiba & \\
W & kiba & \\
\hline 122 & & *kamu: \\
SUN & & \\
M & kamu & \\
W & kamu: & \\
\hline 123 & & \\
SWEET POTATO & *kaCiti: \\
M & kati & \\
W & ka:zi: &
\end{tabular}

The $t: z$ correspondence is quite irregular. Outside of Pidjanan (PAYNE, 1991, p. 420, RAMÍREZ, 2001, p. 641), cognates have extra syllables: Baniwa-Curripaco kadiui, Lokono halithi, etc. This suggests a trisyllabic solution for ProtoPidjanan, with $M$ ti and $W$ zit: reflecting different syllables. $W$ long a: could be explained as compensatory lengthening for the loss of the middle syllable, and $M$ ti as a direct continuation of the middle syllable, which would then be *ti or *tsi, the latter agreeing with the palatal $\mathrm{c}\left[\mathrm{t}^{\mathrm{j}}\right]$ in closely related Bahuana keci (RAMíREZ, 1992, p. 117). Note that irregular syllable 
loss is necessary in both languages (*tsi in Wapishana, *ri: in Mawayana). Another possibility is that only middle $*_{i}$ was lost (as in MANIOC), creating a *tsr or *tr cluster that gave rise to $\mathrm{M} t$ and $\mathrm{W} z$. Given this uncertainty, an undetermined consonant ${ }^{*} \mathrm{C}$ is reconstructed for the middle syllable.

\begin{tabular}{lll}
\hline 124 & & \\
TAPIR & *kudui \\
M & kudi & \\
W & kudui &
\end{tabular}

\begin{tabular}{ll}
\hline 125 & *kiwa:da
\end{tabular}

$\begin{array}{lll}\mathrm{M} & \text { ri-kiwad-e-si } & \text { 'he tells it' } \\ \mathrm{W}_{1} & \text { kuwa:da-n } & \text { 'tell' }\end{array}$

$M$ stem-final a becomes e in verbs in the present tense. Therefore, $M_{3} \mathrm{e}$ implies a stem-final a. Furthermore, the $\dot{i}$ : u correspondence suggests assimilation (*kiwa:da > W kuwa:da); $*_{i}$ is thus reconstructed (cf. FLOWER).

\begin{tabular}{lll}
\hline 126 & & \\
TERMITE & $*$ mari \\
M & mariba & \\
$\mathrm{W}_{1}$ & mazi & \\
\hline 127 & & \\
THIN & & $*$ miCa- \\
$\mathrm{M}_{1}$ & metada & \\
$\mathrm{W}_{1}$ & mida?; &
\end{tabular}

The irregular $\mathrm{t}: \mathrm{d}$ correspondence is reconstructed as an undetermined consonant ${ }^{*} \mathrm{C}$. Notice also i-to-e raising due to the following a. On the other hand, the possibility of non-cognacy cannot be excluded.

\begin{tabular}{lll}
\hline 128 & & \\
THORNBUSH & $*$ Cawiri \\
M & tawisi & \\
W $_{1}$ & kawizi
\end{tabular}

$W_{1}$ listed as an unidentified plant; $\mathrm{W}_{2}$ lists kawiz as a species of thornbush known as 'rabo de camaleão' (lit. chameleon tail). All correspondences are regular, except the initial consonants $\mathrm{k}$ and $\mathrm{t}$. An undeter- mined stop ${ }^{*} \mathrm{C}$ is reconstructed to signal uncertainty about the initial consonant.

\begin{tabular}{llc}
\hline 129 & & \\
THROAT & *kurukuru \\
M & ri:-kurukuru & \\
W $_{1}$ & kurukuru-n & 'larynx' \\
\hline 130 & & \\
TICK & & *kuCVCVba \\
M & kunuriba & \\
W & kurinaba &
\end{tabular}

The two medial syllables have apparently undergone metathesis; their original order is unclear. This is signaled by reconstructing undetermined ${ }^{*} \mathrm{CVCV}$ syllables. W first a forms an irregular i : a (or $u$ : a, prior to methatesis) corresponddence, with no clear argument favoring $*_{\mathrm{i}}, *_{\mathrm{u}}, *_{\mathrm{a}}$, or any other vowel; it is thus reconstructed as an undetermined *V.

\begin{tabular}{lll}
\hline 131 & & \\
TIMBÓ LIANA & *uku \\
M & uku & 'timbó liana' \\
W & uku & 'poison for fish' \\
\hline 132 & & \\
\multicolumn{2}{l}{ TINAMOU SP. } & *mami \\
M & mami & 'tinamou sp.' \\
W2 & mami & 'bird sp.'
\end{tabular}

$W_{1}$ has no final vowel (mam). This variation clearly results from ongoing unstressed vowel loss.

\begin{tabular}{lll}
\hline 133 & & \\
TOAD SP. & *tururuba \\
M & tfururuba & \\
$W_{1}$ & tururuba & \\
& & \\
\hline 134 & & $*$ \\
TOBACCO & \\
M & tuma & \\
W & su:ma & \\
\hline 135 & & \\
TONGUE & *ninuba \\
M & ri-jũjũba & \\
W & i-ninuba &
\end{tabular}

$M$ first syllable was seemingly reduplicated (PP *ninuba $>$ *ĩ.ũba $>$ *jũba $>M$ jũjũba) or assimilated (PP *ninuba > *ĩ.ũba > *jījũba > M jũjũba). In either case, the change is irregular.

\begin{tabular}{lll}
\hline 136 & & \\
TORTOISE & $*$ wirV \\
M & u:ri & \\
W & wirada &
\end{tabular}

The $\dot{t}$ : a correspondence is irregular; only an undetermined vowel *V can be reconstructed.

\begin{tabular}{lrl}
\hline 137 & & \\
TOUCAN SP. & *ta:kui \\
M & takwe & 'toucan sp.' \\
W & ta:kui & 'toucan sp.'
\end{tabular}

The e : i correspondence is reconstructed as *i also here; note the preceding a. The kw : ku pair suggests a more complex story (maybe from *ku-wi?). This makes the reconstruction less satisfactory, since it further separates $*_{a}$ and $*_{i}$. Note also that $\mathrm{W} t \mathrm{t} a: k u i$ has stress on the penultimate segment ([úi]), while M takwe has it on the last segment ([wé]).

$\overline{138}$
TREE/WOOD *atamina
M atfamina
W atamin, atamini

$W_{4}$ atamini has a final $\dot{i}$, but this may result from confusion due to $W$ ongoing loss of unstressed vowels. Therefore, $\mathrm{M}$ a is reconstructed.

\begin{tabular}{|c|c|c|}
\hline \multicolumn{3}{|l|}{139} \\
\hline \multicolumn{2}{|c|}{ TREE TRUNK } & *kadi- \\
\hline $\mathrm{M}$ & ri-kadi & \\
\hline$W_{1}$ & i-kadina: & \\
\hline \multicolumn{3}{|l|}{140} \\
\hline \multicolumn{2}{|c|}{ TRUMPETER } & *namVtfi \\
\hline$M$ & namiti & 'jacamim' \\
\hline $\begin{array}{l}\mathrm{W}_{1} \\
\text { trun }\end{array}$ & $\begin{array}{l}\text { namatfi } \\
\text { eter' }\end{array}$ & 'gray \\
\hline
\end{tabular}

There are two irregular vowel correspondences, $\dot{i}:$ a and $\dot{\dot{t}}: \mathrm{i}$. The latter 
occurs in a palatalizing environment $(P P * t)$, suggesting that the original vowel is $*_{i}$ and $W i$ its palatalized reflex). The former, however, is quite irregular: only an undetermined vowel *V can be reconstructed.

141

TUCUMÃ PALM *sawara

M sawara 'tucumã'

$W_{1}$ Jawarał 'unidentified palm'

Possible borrowing, since this is a frequent word in Cariban languages, too (Tiriyó awara, Waiwai jawara, both 'tucumã palm'). $W_{1}$ final $\dot{i}$ is probably not part of the stem (else PP *ai > M i, not a); cf. another unidentified palm, $W_{1}$ Jawaram ni:zu, with final $\mathrm{m}$ (or $\mathrm{mV}$ ) instead of $\dot{\mathrm{t}}$.

\begin{tabular}{lll}
\hline 142 & & \\
VULTURE SP. & *kurumu \\
M & kurumu & 'vulture sp.' \\
W $_{1}$ & kurim & 'bird sp.'
\end{tabular}

Possible borrowing, since this is a frequent word in Cariban languages, too (e.g., Waiwai kurumu 'vulture sp.'). Given the Waiwai form, the irregular $u$ : i correspondence is here reconstructed as ${ }^{*} u$.

There is a bird named kuruma in Mawayana (in Port. 'japu', Waiwai kwoto); it may be the true cognate of $W$ kurim instead of $M$ kurumu 'vulture sp.'. If so, the resulting proto-form, reconstructible as *kurVma, is not a likely borrowing.

\begin{tabular}{lll}
\hline 143 & & \\
WALK & & *si?uka? \\
M & ru-suka & \\
$\mathrm{W}_{1}$ & tfiPika-n &
\end{tabular}

This set has two irregular correspondences, $s: t$ (of which it is the only example) and $u$ : i. Given that $k a$ is also a frequent thematic suffix, it is quite possible that the words in this set are not cognate. The above reconstruction is thus very tentative. (NB: *si?uka > *siuka > M suka is regular, but *si?uka $>*^{*}$ si?ika $>$ W $\mathrm{t} \int \mathrm{i}$ ika is not: palatalization of $*_{\mathrm{s}}$ usually yields $* \int$, not $* t$, which also argues against cognacy.)

\begin{tabular}{lll}
\hline 144 & & $*$ wini \\
WATER & & \\
M & uni, u:ni & \\
W & wini & \\
\hline 145 & & \\
WE & & $*$ wainau \\
M & wePawinu & \\
W $_{1}$ & wainau &
\end{tabular}

$M$ initial element we?a remains so far unidentified. Final -nu, -nau may reflect a plural suffix (<PP ${ }^{*}$-nawi).

\begin{tabular}{lll}
\hline 146 & & \\
WHAT/WHO & $*$ ka \\
M & ka & \\
W $_{1}$ & kan, kanum & \\
\hline 147 & & *awari \\
WIND & & \\
M & awari & \\
W $_{1}$ & awari & \\
\hline 148 & & \\
WITH & & $*(i)$ tima \\
M & ri-fima & \\
W & i-tima &
\end{tabular}

The irregular i : † correspondence occurs in a palatalizing environment (the $\int: t$ correspondence reflects a palatalized allophone of $* \mathrm{t}$ ). Therefore, an $*_{i}$ is reconstructed, with $\mathrm{M}$ $i$ being its palatalized reflex.

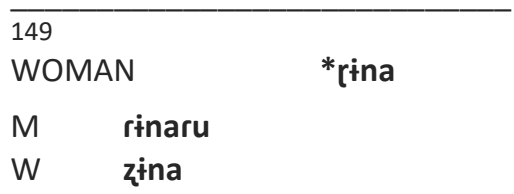

$M$ final ru is probably a reflex of the old third-person feminine suffix -ru (cf. W -zu). It is easier to assume a reinforcement of feminine semantics via the addition of an extra feminine suffix (cf. the current $W$ variant zina:ba 'female, woman, lady', with a more recent feminine marker -aba) than the other way around, which is why the suffixless from is here reconstructed. 